\title{
Generic 3D interpolation of Holocene base-level rise and provision of accommodation space, developed for the Netherlands coastal plain and infilled palaeovalleys
}

\author{
Kay Koster, *,† Jan Stafleu† and Kim M. Cohen*,†, \\ * Department of Physical Geography, Faculty of Geosciences, Utrecht University, Utrecht, The Netherlands \\ $\uparrow$ TNO Geological Survey of the Netherlands, Utrecht, The Netherlands \\ $\$$ Department of Applied Geology and Geophysics, Unit BGS, Deltares, Utrecht, The Netherlands
}

\begin{abstract}
We present an interpolation model that describes Holocene groundwater level rise and the creation of accommodation space in 3D in the Rhine-Meuse delta - the Netherlands. The model area (ca. $12400 \mathrm{~km}^{2}$ ) covers two palaeovalleys of Late Pleistocene age (each $30 \mathrm{~km}$ wide) and the overlying Holocene deposits of the Rhine-Meuse delta, the Holland coastal plain, and the Zuiderzee former lagoon. Water table rise is modelled from 10800 to $1000 \mathrm{cal}$. BP, making use of age-depth relations based on 384 basal peat index points, and producing output in the form of stacked palaeo groundwater surfaces, groundwater age-depth curves, and voxel sets. These products allow to resolve (i) regional change and variations of inland water table slopes, (ii) spatial differences in the timing and pacing of transgression, and (iii) analysis of interplay of coastal, fluvial and subsidence controls on the provision of accommodation space. The interpolation model is a multi-parameter trend function, to which a 3D-kriging procedure of the residuals is added. This split design deploys a generic approach for modelling provision of accommodation space in deltas and coastal lowlands, aiming to work both in areas of intermediate data availability and in the most data-rich environments. Major provision of accommodation space occurred from $8500 \mathrm{cal} \mathrm{BP}$ onwards, but a different evolution occurred in each of the two palaeovalleys. In the northern valley, creation of accommodation space began to stall at $7500 \mathrm{cal} \mathrm{BP}$, while in the southern valley provision of new accommodation space in considerable quantities continued longer. The latter is due to the floodplain gradient that was maintained by the Rhine, which distinguishes the fluvial deltaic environment from the rest of the back-barrier coastal plain. The interpolation results allow advanced mapping and investigation of apparent spatial differences in Holocene aggradation in larger coastal sedimentary systems. Furthermore, they provide a means to generate first-order age information with centennial precision for $3 \mathrm{D}$ geological subsurface models of Holocene deltas and valley fills. As such, the interpolation is of use in studies into past and present land subsidence and into low land sedimentation.
\end{abstract}

\section{INTRODUCTION}

The deceleration of postglacial sea-level rise is heavily reflected in the accommodation and aggradation history of Holocene deltas and coastal lowlands worldwide (Stanley \& Warne, 1994; Hori \& Saito, 2007), despite great differences in values of tectonic and glacio-isostatic background subsidence and quantities of water and sediment delivery. The rise of sea level induced simultaneous rise of the coastal groundwater levels (GWL) over tens of kilometres inland, affecting rivers and lagoon systems.

Correspondence: Kay Koster, Department of Physical Geography, Faculty of Geosciences, Utrecht University, P.O. Box 80.115, 3508 TC Utrecht, The Netherlands. E-mail: k.koster1 (a)uu.nl
Reconstructing the rates and spatial variations of this base level rise is essential for understanding the built-up of these Holocene sequences, as that process governed the accumulation of major sedimentary bodies and the agedepth relations (time lines) within. Being able to assign ages to coastal plain deposits is key to understanding coastal-deltaic architectures and the provision of accommodation space during their built-up.

In northwestern Europe, coastal plain GWL rise over Holocene time scales is commonly reconstructed by using ${ }^{14} \mathrm{C}$ dated basal peat (Jelgersma, 1979; Denys \& Baeteman, 1995; Zong \& Tooley, 1996; Vella \& Provansal, 2000; Streif, 2004; Gehrels et al., 2006; Behre, 2007; Crombé et al., 2015). In the Netherlands, marker peat beds are encountered at the very base of Holocene coastal and deltaic sequences that onlap an assumedly incompressible 


\section{K. Koster et al.}

Pleistocene substrate. The basal peat beds developed when a rising groundwater table made the paleosol at the top of this substrate submerge, a process driven by Early and Middle Holocene sea-level rise. The notion of an incompressible substrate makes the very bottom of the basal peat a suitable time-depth marker for a past water table, supporting the use of series of dated basal peat samples for reconstruction of rise of coastal GWL (Jelgersma, 1961; Cohen, 2005; Vis et al., 2015).

In the Netherlands, ${ }^{14} \mathrm{C}$ dating of basal peat for GWL reconstruction was first applied in the 1950s (Bennema, 1954; Van Straaten, 1954). During subsequent decades a series of regional GWL reconstruction studies have been performed, often in association with relative sea-level rise research aims (e.g. Jelgersma, 1961, 1979; Van de Plassche, 1982; Van Dijk et al., 1991; Gotjé, 1993; Kiden, 1995; Törnqvist et al., 1998; Makaske et al., 2003; Berendsen et al., 2007a; Hijma \& Cohen, 2010; Van de Plassche et al., 2010). These reconstructive studies documented GWL rise and thereby the provision of accommodation space, but focused on creating single reference curves of GWL and sea-level rise, by using data from as small as possible areas, in what is essentially a one-dimensional approach.

Regional variability in hydrological regimes responsible for basal peat growth (Van de Plassche, 1982), morphology of underlying deposits (Jelgersma, 1961), and differential vertical movement of the substrate between regions (Kiden et al., 2002), were the main reason to establish GWL-rise reconstructions at local scale only. To assess river gradient effects on deltaic groundwater tables, twodimensional comparative analysis of the local GWL reconstructions was introduced by Van Dijk et al. (1991) and Törnqvist et al. (1998). They plotted index-points on a longitudinal transect of tens of kilometres long and correlated the data points by manually drawing groundwater table gradient lines between them. This method illustrated the persistent spatial-temporal trends (and deformations therein), but quantifying these was sensitive to choices of a longitudinal projection axis to plot the data points on and compare along. These limitations were overcome by Cohen (2005), who developed a 3D-method to interpolate Holocene GWL rise across the entire Rhine-Meuse delta. The first analyses used some 300 ${ }^{14} \mathrm{C}$-dated basal peat index points (extracted from a database maintained at Utrecht University: Berendsen \& Stouthamer, 2001; updated: Cohen et al., 2012). The interpolation was initially designed as part of a project focused on differential subsidence as recorded in relation to deltaic accommodation (Cohen, 2003, 2005; Cohen et al., 2005). Hereto, it predicted water table depths with ages, documenting the creation of accommodation space in $3 \mathrm{D}$ through time due to combined water table rise and substrate subsidence. Since then, it has found application in further Rhine delta studies needing temporal quantification of accommodated volumes and predictions of consolidation-free age-depth positions in flood basin sequences (e.g. Gouw \& Erkens, 2007; Hoffmann et al.,
2007; Stouthamer et al., 2011; Van Asselen, 2011; Bos et al., 2012). A limitation of the 2005 setup, however, was that by its design the interpolation method was restricted to a coastal-deltaic plain study area that is centred over the axis of a single palaeovalley. The application of the method over a larger coastal plain with larger area requires further conceptual development to overcome that limitation.

Palaeovalleys are common phenomena in the substrate of deltas and coastal plains (e.g. Yangtze: Wang et al., 2013; Tokyo Kanto Plain: Tanabe et al., 2015; Mississippi: Blum et al., 2008; Mekong: Hanebuth et al., 2012). Buried palaeovalleys are topographically complex, as a result of different sizes and lifespans of valley forming rivers and receiving basins. Also, where elongated coastal plains are fed by chains of smaller rivers (e.g. Northern Adriatic Sea: Fontana et al., 2008; Southern Italy Metaponto plain; Tropeano et al., 2013; Waddensea coast: Vos \& Knol, 2015), accommodated thickness greatly varies as the coastal plain traverses multiple palaeovalley axis. This underpins the need for an interpolative accommodation modelling method, to be able to deal with complex spatial diversity in accommodated thickness and isostatic subsidence as a factor, which are the main issues addressed in the redesign of the Netherlands' coastal plain GWL rise $3 \mathrm{D}$ interpolation model. In this article, we add the Holland coastal plain and the Zuiderzee former lagoon to that of the Rhine-Meuse delta coastal plain, enlarging the area by a factor of three, and include a northern and a southern palaeovalley in the substrate (Fig. 1). Both valleys were formed by Last Glacial precursors of the river Rhine.

The number of basal peat index-points from the Netherlands has continued to grow in the past decade, in particular owing to Middle Holocene sea-level rise studies (Hijma \& Cohen, 2010; Van de Plassche et al., 2010), land subsidence studies (Van Asselen, 2011) and archaeological studies (Makaske et al., 2003; Vos et al., 2015a), allowing the extension of the model and adapting the method.

In this article, we present a generic 3D-interpolation model for GWL rise and creation of accommodation space in complex coastal and deltaic plains, renewing earlier work in the Netherlands, and making use of updated input data $\left({ }^{14} \mathrm{C}\right.$-dated basal peat GWL index-points) and software environments for 3D geomodelling (see below). In our new adapted approach we consider (i) the spatial expansion of the interpolation area (to include a second buried palaeovalley), (ii) establishment/definition of lower and upper bounding surfaces (for resp. 10800 and 1000 years ago) for the expanded model area, (iii) an update of data coverage for the extended model area, (iv) modification of the original interpolation methodology to deal with the new spatial extent and data distributions, and (v) comparison of the 3D GWL interpolation with sedimentary surfaces of existing $3 \mathrm{D}$ geological subsurface models. This resulted in a high-resolution $3 \mathrm{D}$ interpolation of coastal-lagoonal and deltaic GWL for the Holocene (excluding the period of human interferences in the youngest 1000 years), for an area of approximately 
Fig. 1. Digital elevation model of the top of Pleistocene substrate extracted from GeoTOP. It represents its configuration during the onset of the Holocene.

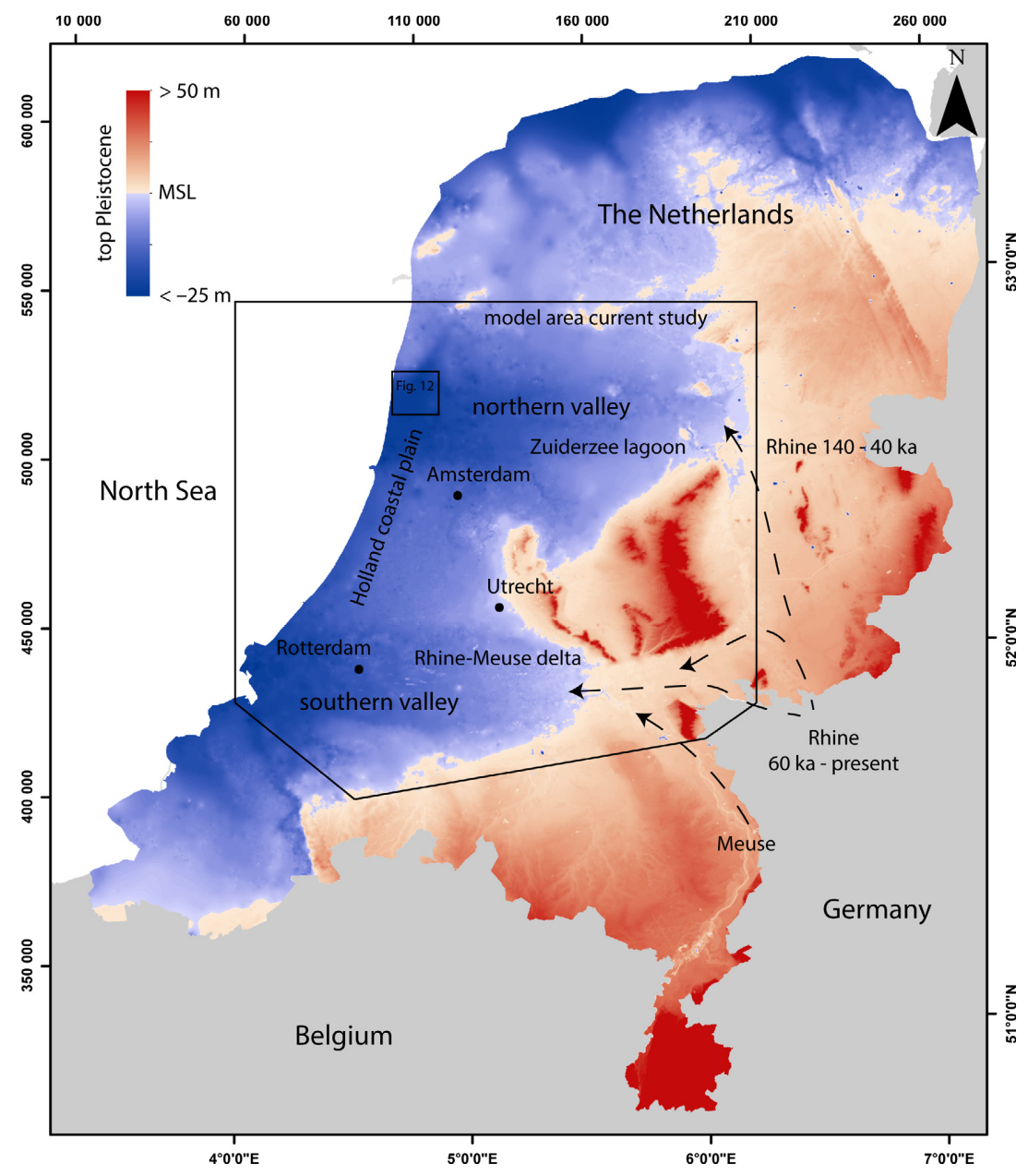

$150 \times 160 \mathrm{~km}$ at an resolution of $1000 \times 1000 \mathrm{~m}(x, y)$ and an age-depth resolution of 200 year $(t)$ and $0.5 \mathrm{~m}(z)$. The GWL interpolations allow to adding age information to the cells of the 3D geological mapping products, helping to advance research into sediment budgets, palaeogeographical reconstructions and landscape-archaeological developments of Holocene coastal-deltaic depositional environments.

\section{Geological setting}

The Netherlands is situated near the southern margin of the North Sea basin, which owes it present pattern of subsidence to youngest tectonic reorganizations in the Early Miocene (Zagwijn, 1989; Van Balen et al., 2005). Superimposed vertical movements forced by glacio-isostatic adjustment (GIA) are also in effect (Lambeck et al., 1990), owing to Pleistocene glaciation of nearby Scandinavia and Northern Britain. Peripheral forebulge GIA across the Netherlands induces a north-northeastward tilt in overall land subsidence since $c a .20 \mathrm{ka}$ and throughout the Holocene (Cohen et al., 2002; Kiden et al., 2002; Vink et al., 2007). The study area is positioned on the southern flank of the collapsing forebulge at that time. The forebulge crest of the last glaciation - and hence the zone of maximum Holocene GIA-driven subsidence runs north of the study area (stretching from the central
North Sea/Dogger Bank, via northern Germany towards central Poland; Steffen \& Wu, 2011). As a consequence of GIA, the absolute vertical position of basal peat deviates from its initial position during formation, and since GIA extends far beyond the southern boundary of the study area (Lambeck, 1997; Lambeck \& Purcell, 2005), all basal peat in the study area has experienced considerable postsedimentary vertical displacement. No exact breakdown of total relative base level rise into components of GIA subsidence (forebulge collapse), background tectonic subsidence, and eustatic sea-level rise (i.e. increased ocean volume) is available, but it would be spatially and temporally variable within the study area.

The southern of the two east-west orientated Late Pleistocene river valleys that traversed the study area (Fig. 1) is that of the Rhine system in the youngest 60000 years (activated within MIS-3; Busschers et al., 2007). It owes its buried morphological expression to Lateglacial and Early Holocene developments mainly (Hijma \& Cohen, 2011). In the centre of the valley, the active width of channel belts contracted into a narrow zone in response to climatic amelioration from MIS 2 to MIS 1, and inland dune complexes started to develop locally on the floodplain that formed the valley floor (Hijma et al., 2009; Vos et al., 2015a). The palaeovalley in the north marks the precursor Late Pleistocene palaeovalley (active in MIS 4-3), in use by the Rhine up to 


\section{K. Koster et al.}

ca. 40000 years ago and thereafter used by the considerably smaller rivers Vecht and Eem, coinciding with some aeolian activity (e.g. Peeters et al., 2015, 2016). Both valleys extend offshore and merge with the Thames in the Southern North Sea, to continue southwestward (e.g. Hijma et al., 2012).

The valleys are topographically separated by an icemarginal ridge complex from the penultimate glaciation (Busschers et al., 2008). During the Last Glacial Maximum and the Late Pleniglacial (MIS 2), the flanks of both valleys and their interfluve where blanketed with aeolian sands. The elevation of the top of the Pleistocene deposits of the northern valley ranges between $-1 \mathrm{~m}$ and $-22 \mathrm{~m}$ relative to present mean sea-level (MSL). The southern valley slopes between approximately $5 \mathrm{~m}$ and $-22 \mathrm{~m}$ relative to MSL. The coastal plain (in part a deltaic plain) covers the southern valley to approximately $150 \mathrm{~km}$ inland of the modern coast line. The northern valley is covered by some $120 \mathrm{~km}$ of inland coastal plain extent (Fig. 1).

The Holocene prism that buried the palaeovalley floors and interfluves consists of tidal deposits and coastal barriers that developed under control of middle Holocene decreasing relative sea-level rise (e.g. Beets \& Van der Spek, 2000), and which are intercalated with coastal peats. In the last 6000 years, once relative sea-level rise had decreased and the North Sea had reached roughly its present depth, the palaeo-tidal ranges have been stable (Van der Molen \& De Swart, 2001). These mesotidal conditions had established during the last millennia of transgression, between 8500 and 6500 year (Hijma \& Cohen, 2010). In the southern valley, the coastal deposits interfinger with estuarine and fluvial clastics and organics (e.g. Van der Woude, 1984; Berendsen \& Stouthamer, 2001; Hijma et al., 2009; Bos et al., 2012). The many intercalated peat beds in the various environments of the complex coastal plain are used as the source deposits for the input data in the study $\left({ }^{14} \mathrm{C}\right.$-dated basal peat index points), and their distribution echoes in the coverage and (un)even spread of that data.

\section{MATERIALS AND METHODS 3D modelling environment}

The Netherlands is regarded as one of the most intensively geologically mapped areas of the world. A recent achievement of TNO-Geological Survey of the Netherlands (TNO-GSN) is the construction of a high-resolution 3D model of the upper 30-50 m of the subsurface of the onshore part of the Netherlands, known as GeoTOP (Stafleu et al., 2011, 2012; Van der Meulen et al., 2013; Maljers et al., 2015; www.dinoloket.nl/en). GeoTOP is a $3 \mathrm{D}$ geological voxel model. Its primary input data are extractions from DINO, the national Dutch subsurface database operated by TNO-GSN (Van der Meulen et al., 2013). At the moment of the construction of GeoTOP, this database contained about 425000 digitized borehole descriptions. In the Rhine-Meuse delta part of the study area, these input data are supplemented by some 125000 additional shallow borehole descriptions of Utrecht University (Berendsen et al., 2007b). Various further digital geological mapping products serve the model procedures of the primary data in the construction process. GeoTOP has a resolution of $100 \times 100 \times 0.5 \mathrm{~m}$ and each voxel is attributed with lithostratigraphical and lithological class information (including grain-size classes for sand) and the probability of occurrence for each of the lithological classes (Stafleu et al., 2011, 2012).

The software infrastructure for this $3 \mathrm{D}$ modelling set up makes use of Isatis ${ }^{\circledR}$ geostatistical software (www.geovariances.com) and Python-scripted workflows. That setup motivated to implement the modified method for interpolating Holocene GWL rise in this same software infrastructure. This means that besides lithological data (strata from borehole descriptions) also age information (GWL index-points) becomes utilized in the 3D modelling set-up. Performing both the modelling of sedimentary surfaces and that of former groundwater tables in the same environment is essential for cross-verification of both type of modelling results. The combined use of GeoTOP and GWL interpolation would enable the comparison of predicted elevations of past groundwater tables, with encountered depths of sedimentary surfaces of the same age (within radiocarbon-dating and mappingsystematic accuracy). Having the GWL interpolation running within the software environment is a preparatory step to the introduction of 'age' as a future attribute for Holocene coastal and deltaic plain GeoTOP-voxels.

\section{Interpolation methodological design}

The core of the 3D GWL interpolation is to fill an $x, y, t$ grid with attribute depth (z), i.e. the depth of a GWL at a certain location in time. The steps of the interpolation are schematically represented in Fig. 2a-c. For each combination of $x, y, t$ the attribute $z$ is calculated in two steps, (i) a trend function prediction calibrated to the set of observations, supplemented by (ii) 3D-kriging of residuals to optimize the interpolation locally (as in Cohen, $2005)$. The result can be queried for a given age $(t)$ to produce maps $(x, y 2 \mathrm{D}$ grids) that display elevation of a past groundwater surface (stacked surfaces output method). One can also query the output for a given location $(x, y)$ to produce a $t, z$ grid that shows GWL rise (local age-depth curve output method). As an additional step in our workflow, we converted the $z$-attributed $x, y, t$ model to an $x$, $y, z$ grid, in which each cell is attributed an age $(t)$ (voxel resampling output method). The latter serves the crossverification of GWL output with GeoTOP geomodelling output.

In the vertical direction, the interpolation is bounded by a lower and an upper surface representing GWL for the beginning and the end of the considered period (10 800-1000 cal. BP). These bounding surfaces function as envelopes around the cloud of Holocene GWL indexpoints data that are the main input for the interpolation. 
The lower bounding surface represents the earliest Holocene groundwater lowstand at the end of glacial-interglacial climatic amelioration (see also: Hoek \& Bohncke, 2002; Cohen, 2005). The upper bounding surface is the Late Holocene groundwater highstand, just prior to major deltaic wetland landscape modification of the Middle Ages, well-known from historical sources for the region (Borger, 1992; De Bont, 2015). Both bounding surfaces were constructed independently from the spatial distribution of the index points, and are based on geological mapping and palaeohydrological insights for the respective time periods.

\section{Indicative meaning of peat index-points}

The index-points derive from peat formed in floodbasins where the water levels were controlled by the North Sea, by the rivers Rhine and Meuse, by local hydrological regimes (seepage, brooks), and in transitional zones of control interplay. Peat formed in semi-annually inundated floodbasins of rivers, grows towards and preserves below the water levels that are maintained throughout an average year, and that tend to coincide with average water levels in the rivers themselves (Van Dijk et al., 1991; Kiden, 1995; Cohen, 2005). In contrast, the peat formed under hydrological regimes of semi-diurnal tidal waters, grades to the high-tide water level in the part of the tidal system to which the peatland drains. This is because the tidal inter-flood episodes last much shorter $(6 \mathrm{~h})$ than typical fluvial inter-flood periods (6-10 months), enabling the peat hydrological system to hold more of its rainfalland flooding received volumes of water. High tide water levels, however, vary considerably along larger tidal inlet systems. In places near the coast they may be amplified relative to open sea tides, whereas in more inland upper estuarine and fluvial-tidal reaches they tend to dampen and be river-gradient co-affected (Van Veen, 1950; Van der Spek et al., 2001). The groundwater signal captured by spreads of basal peat points (as interpolated in our study) thus represents a mean superregional GWL, irrespective of the responsible hydrological regime. Knowledge of the different GWL control regimes aids interpretation and discussion of the interpolation results. Where it has its lowest point, it will represent areas with dampened tide and water levels just above contemporary mean sea-level (Van de Plassche, 1995), whereas in other places - due to tidal and fluvial gradients in average water level - a level decimeters to metres higher (Cohen, 2005; Vis et al., 2015). A time-series of superregional GWL surfaces serves as a series of upper bounds, defining growth of accommodation space over time for a given area.

\section{Data preparation}

The following section briefly lists the preparation steps of the input data for the 3D interpolation, visualized in Fig. 2a. The earlier used ${ }^{14} \mathrm{C}$ index point dataset
(Cohen, 2005) consisted of 330 GWL index points which all derive from the southern palaeovalley and its shoulders. We removed some of the originally included index-points, where these were more indirect GWL indicators from other sources than actual basal peat (i.e. top-soil humic clay, charcoal-dates from archaeological contexts) and some basal peat points with reviewed indicative meanings (e.g. Berendsen et al., 2007a; Van de Plassche et al., 2010). In total 76 previously used index-points were excluded form the original dataset.

A literature study was conducted to collect and add ${ }^{14} \mathrm{C}$ dates and associated GWL index points newly acquired in the southern palaeovalley since 2002 when the GWL dataset was last compiled, andfrom the northern half of the study area, outside the study area of earlier work. A total of 130 additional index points were added, summing the final dataset to a total of 384 , of which 95 are located in the northern and 289 in the southern valley. Full overview of the index point dataset, including metadata and errors, is provided in the Appendix S1. The radiocarbon ages of all GWL index points were (re)calibrated to calendar years BP using OxCal 4.2 (Bronk Ramsey, 2009) and the IntCal13 calibration curve (Reimer et al., 2013).

The index-point dataset bears a difference in density of observations between the southern and the northern valley. It results from contrasting past research attention and data gathering intensities between the Rhine-Meuse delta (including heavily build-over Rotterdam and its harbour) and the coastal plain of North Holland and the former Zuiderzee lagoon.

The second inputs constraining the interpolation are the upper and lower enveloping surfaces. Their extent and elevation defines the horizontal and vertical dimensions of the groundwater interpolation model (Fig. 3a, b). The Appendix S1 provides the argumentation concerning the construction of the digital elevation models (DEMs) for the lower- and upper bounding surfaces, based on Top-of-Pleistocene geological mapping and historical (medieval) information on natural groundwater situation in the delta plain, prior to large scale human land reclamation. The lower bounding GWL surface that was used is based on geological mapping of the top of the palaeovalleys and coversand interfluves, and is displayed in Fig. 3a. We assign it an age of $10800 \mathrm{cal} \mathrm{yr}$ (Rammelbeek Phase, e.g. Bos et al., 2007).

The upper bounding surface is displayed in Fig. 3b. For this bounding surface, the difference with the earlier work is the age assigned to the upper bound surface. Cohen (2005) considered the highstand surface 'groundwater as it would be at present in absence of man'. In this study, the groundwater surface at 1000 cal BP is preferred to use as the upper bound. The motivation for this is that in the Netherlands the $10^{\text {th }}$ century AD marks the onset of large-scale hydrological management of the delta and coastal plain, with constructed embankments, drainage systems and other waterworks holding water levels at artificially lower positions, nowadays in places up to 
(a)

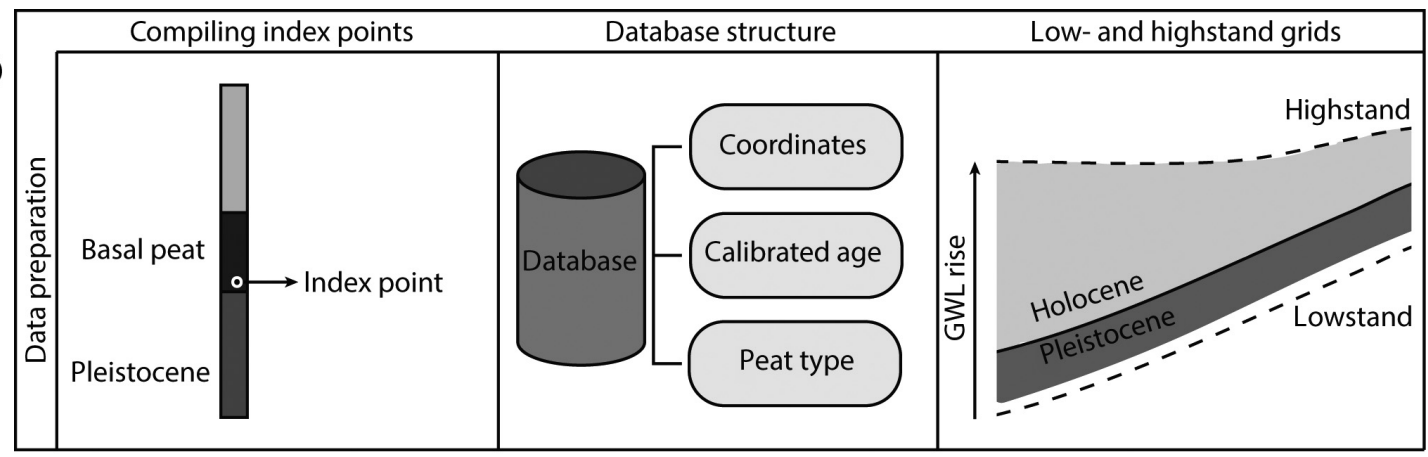

(b)
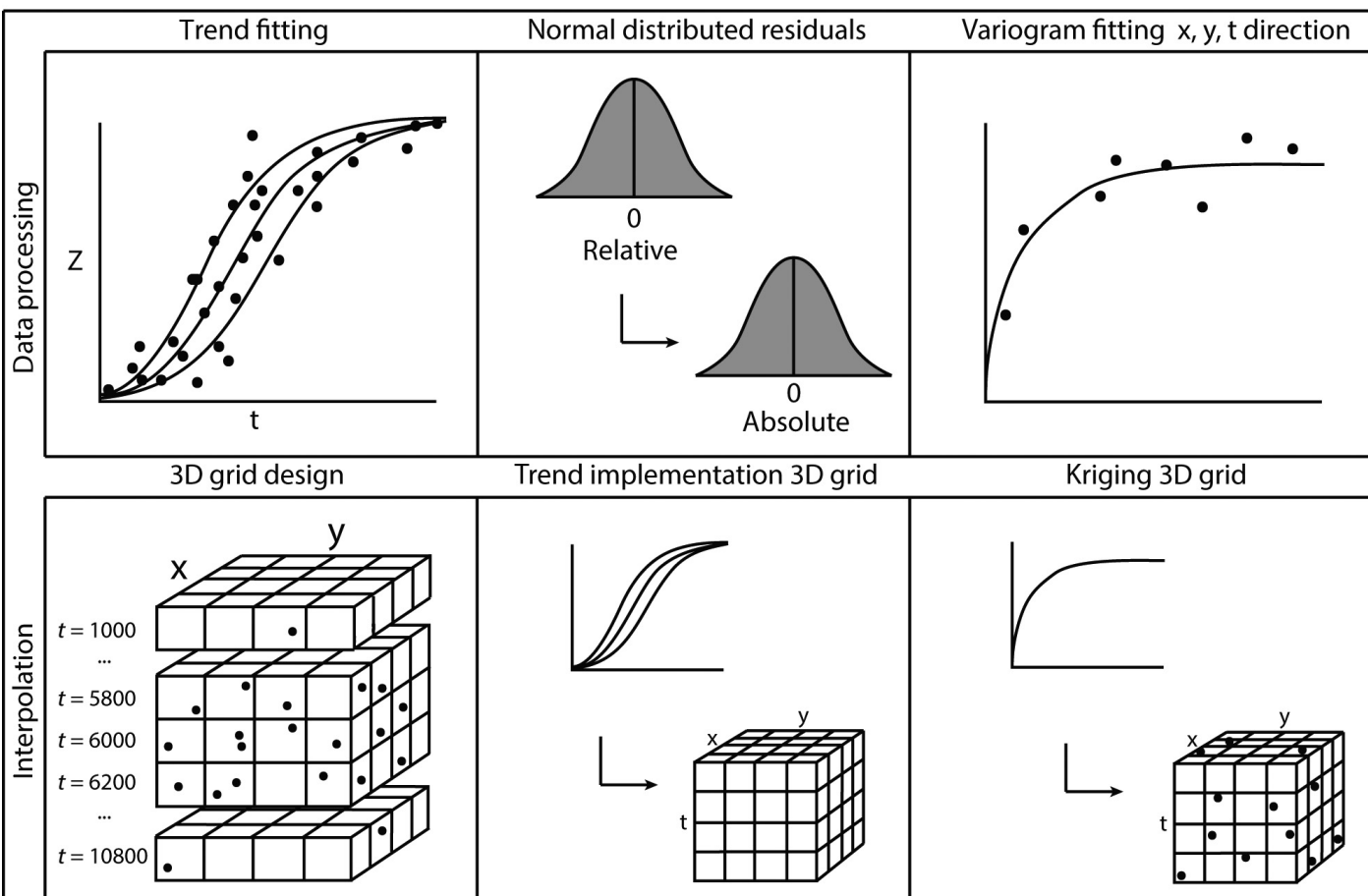

Trend implementation 3D grid

Kriging 3D grid

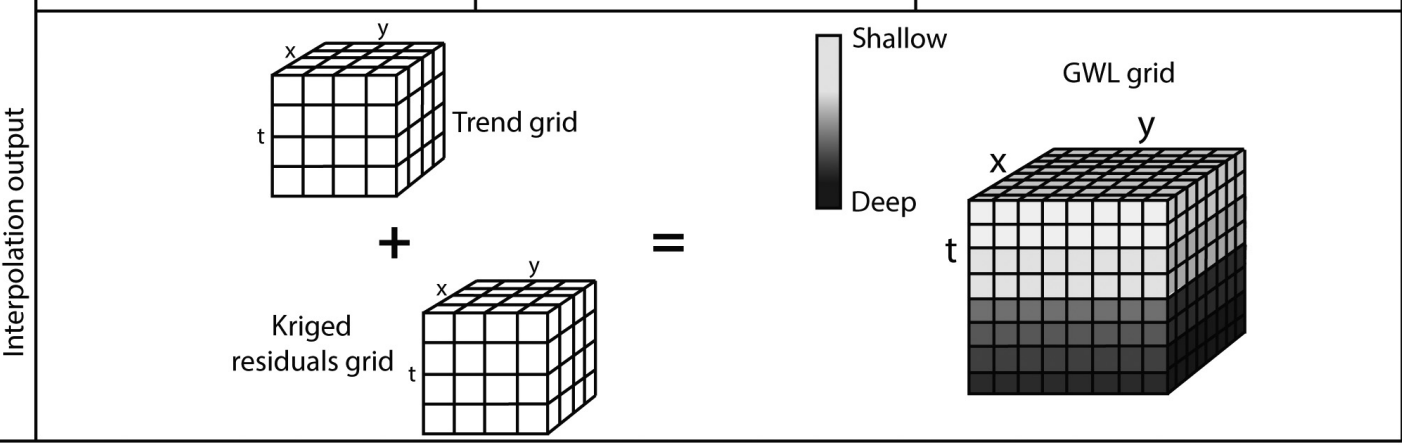

(c)

Stacked surfaces $\quad$ Local age-depth




\section{(a) Lowstand $10800 \mathrm{cal} \mathrm{BP}$}

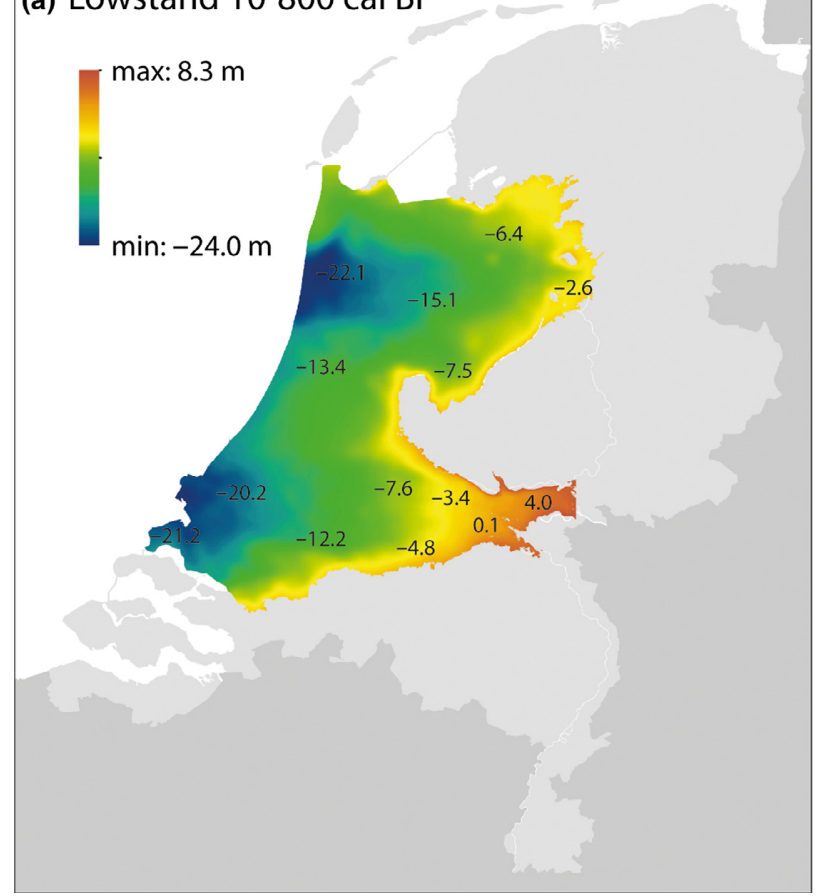

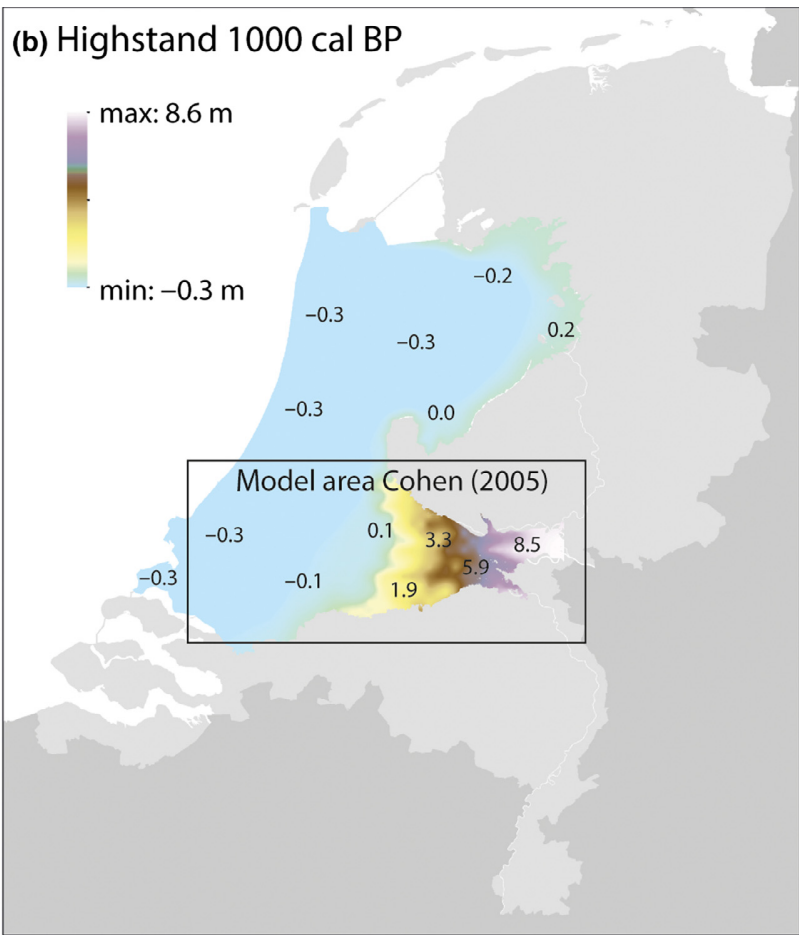

Fig. 3. (a) Lowstand regional groundwater table surface $z_{A 0(x, y)}$, at $10800 \mathrm{cal} \mathrm{BP}$. (b) highstand regional groundwater table surface $z_{A 1(x, y)}$, at $1000 \mathrm{cal} \mathrm{BP}$.

6 m below MSL (e.g. Borger, 1992). Therefore, the interpolation restricts itself to the period of natural GWL rise and considers $1000 \mathrm{cal} \mathrm{BP}$ the final situation.

\section{Data processing}

The data processing steps visualized in Fig. 2b. Within the vertical space between the bounding surfaces, the agedepth relations were interpolated using the observational GWL index point data. The interpolation procedure consists of three steps: (i) a trend function was designed (graphic depiction in Fig. $4 \mathrm{a}-\mathrm{f}$; equations $1-5$ below), that spatially describes the on age-depth relations and is calibrated by least-square regression on the normalized elevation (Fig. 4a) of the index points (observation locations; Fig. 4e), (ii) this trend function was applied to the $x, y, t$ grid, which yields a GWL position between the lower and upper bounding surface for each prediction location (Fig. 4b-d), and (iii) a kriging interpolation was applied on the obtained residuals (observed minus predicted elevation) to the trend function to optimize the interpolation regionally. At any cell in the grid, this then predicts GWL rise through time, from which the timing of local drowning, rate of GWL rise and age of accommodation space can be extracted.
The trend function design captures the spatial relations between depth and age of basal peat and expands on a precursor equation in Cohen (2005). This is derived from (i) the dip of the palaeovalley and thickening of transgression in coastal direction (parameter $q_{(x, y)}$ in the exponent of Eqn. 1), and (ii) the dip of the palaeovalley floor in the direction of maximum subsidence (parameter $c_{(x, y)}$ as a co-efficient in Eqn. 1, regionalized using Eqn. 4). From Quaternary geological mapping and Holocene sea-level studies (references in introduction), it is known that these dips are in westward and north-northeastward directions, respectively.

To prepare the index points for trend fitting, their vertical position was expressed as a relative position $Z n_{(x, y)}$ between the lowstand and highstand bounding surfaces (set to 0 and 1 , respectively), and their age as a relative age $p_{(t)}$ between 1000 and 10800 years ago (set to 1 and 0 , respectively). In this $t$ - and $z$-normalized form, data point series for point-locations collapse to a sigmoid-shaped distribution (the typical shape of sea-level curves for the region, with a prelude of slower GWL in advance of transgression) and, hence, the function design (Eqn. 1) used a logistic sigmoid $\left[1 /\left(1-e^{-a X^{b}}\right)\right]$ as the dominant term. This sigmoidal shape is a reflection of how relative sea-level rise

Fig. 2. Schematic representation of the workflow. (a) First, ${ }^{14} \mathrm{C}$ dated basal peat index points were collected and stored in a database and the bounding surfaces were computed - all as input to the interpolation. (b) Next, the dataset was numerically prepared for execution of the trend function + kriging 3D interpolation, outputting coastal groundwater levels (GWL)-elevations $z$ to an $x, y, t$ grid. (c) Post-processing steps prepare the 3D output for visualization in various forms: as flying carpets, as age-depth curves, as resampled voxel sets (original output resampled to an $x, y, z$ grid; with each cell assigned GWL age $A_{(t)}$ ). 
Age cal BP

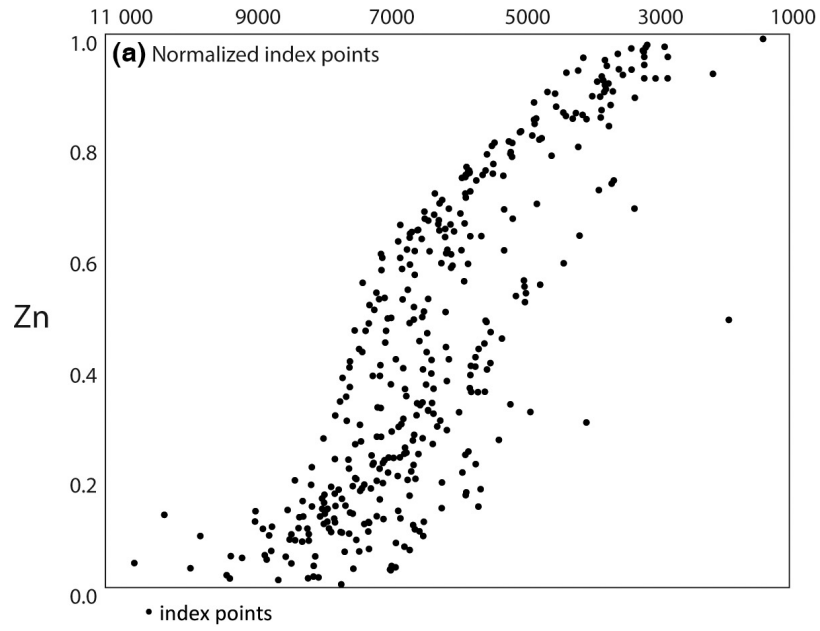

\section{Age cal BP}
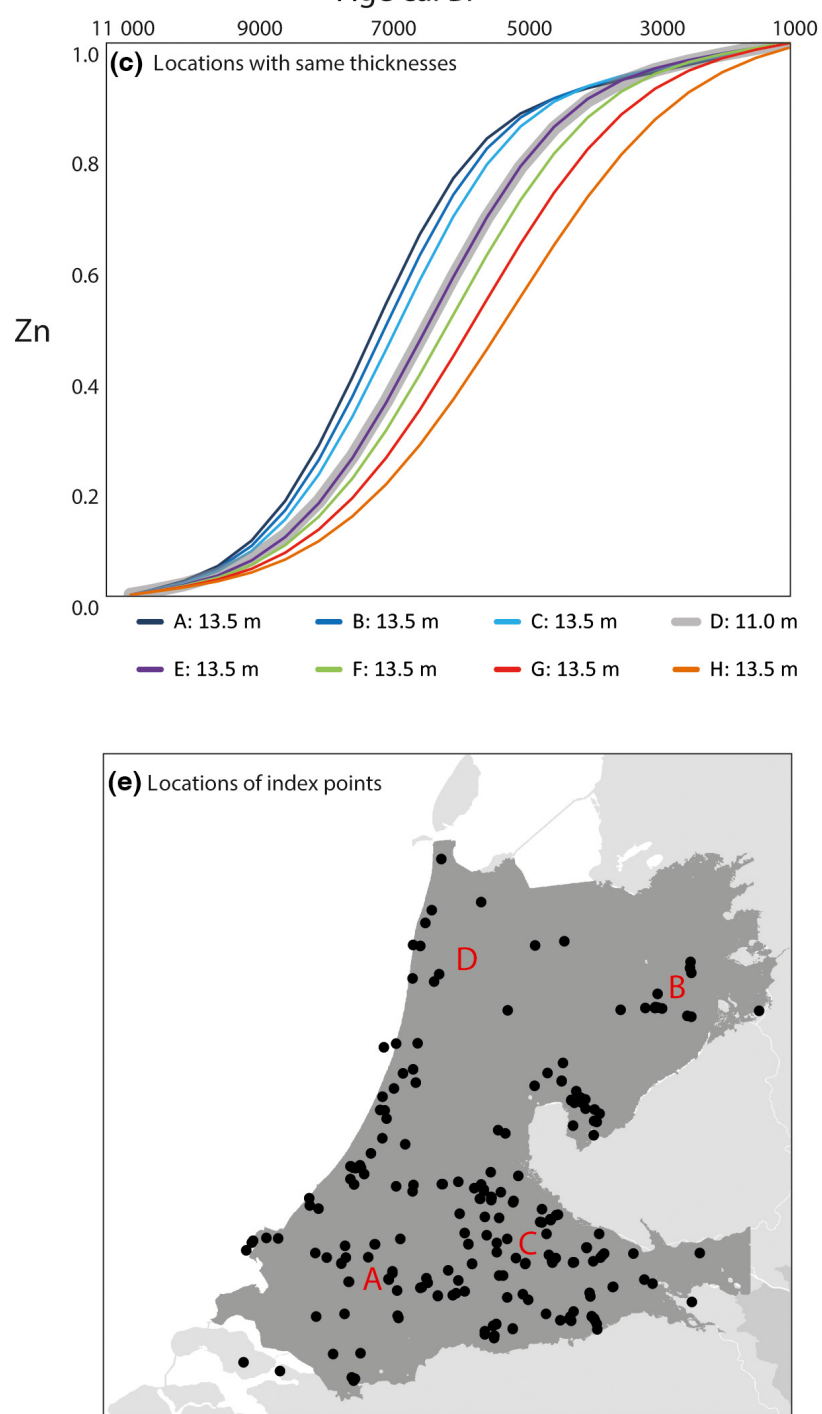

affected relative GWL rise, and it includes combined contributions from regional land subsidence and global ocean volume increase (eustasy).
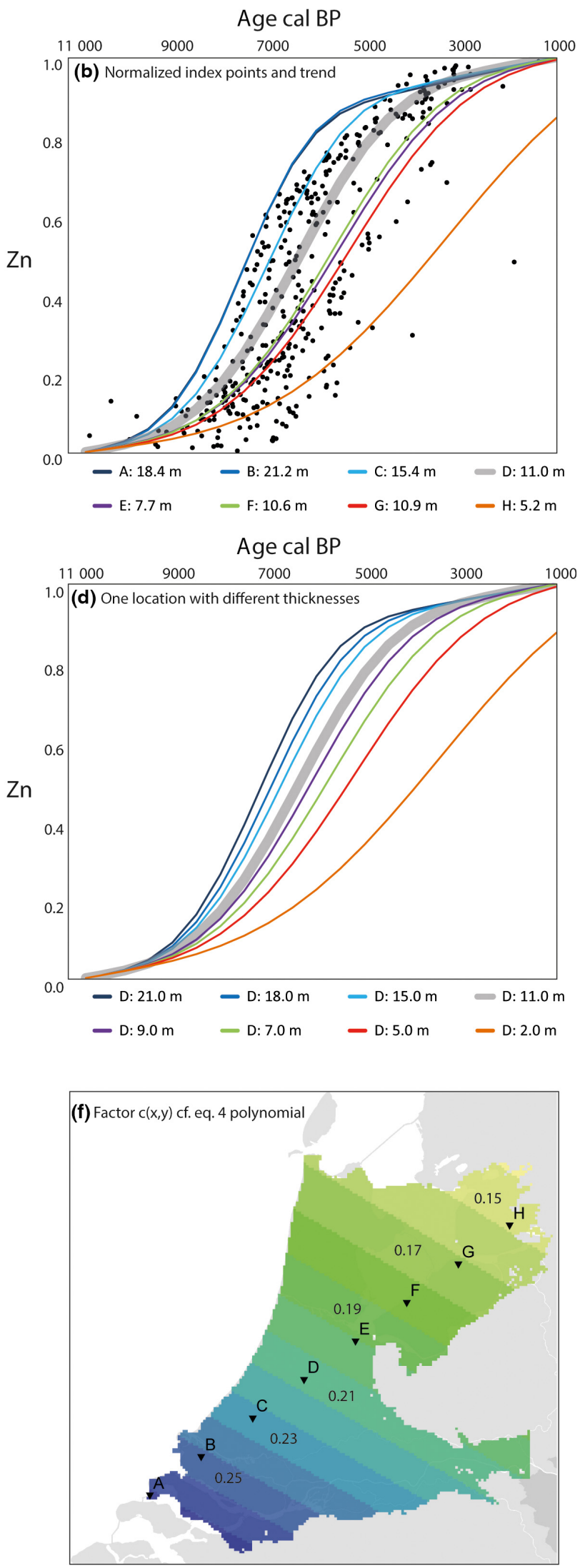

Over the Holocene, index points got vertically displaced due to ongoing subsidence, at increasing rates in north-northeastern direction within the study area, and in 
Fig. 4. (a) Plot of normalized depth $(Z)$ vs. age of index points cal BP. The distribution is sigmoid shaped. 4B Plot of coastal groundwater levels (GWL) curves according to our trend function, for eight locations (shown in panel f). Normalization of the data makes each line commence at the origin, which represents the GWL at lowstand, when over most of the palaeovalleys and interfluves it sat below the top of the Pleistocene substrate. In areas where the total Holocene thickness is large (e.g. curves a and b), the curves rise early and steep and the $50 \%$ mark is passed around $7 \mathrm{ka}$. Where total thickness is less (e.g. curves e and f), the curves are less steep and the $50 \%$ mark is surpassed centuries to millennia later. (c) Plots of the trend function for the same locations (panel f), but now with equal thickness (set to $13.5 \mathrm{~m}$, a representative area-averaged value). In the equations, this keeps $q_{(x, y)}$ constant and thus indicates the sensitivity to the parameterization of $c_{(x, y)}$ (linear background subsidence). (d) Plots of trend function for one central location (d in panel f), now with varied Holocene thickness. This keeps $c_{(x, y)}$ constant and varies $q_{(x, y)}$ and illustrates the sensitivity of the sigmoidal term (non-linear part of base-level rise). (e) Locations of the basal peat index points, and the in red, the locations of the curves presented in Fig. 8. (f) Spatial distribution of factor $c_{(x, y)}$, resulting from second order polynomial parameter calibration for Eqn. 4, and representing the trade-off between the linear and non-linear (sigmoidal) parts in the full trend function (Eqn. 1). The least-square regression-derived distribution for this factor mimics patterns of glacio-isostatic adjustment (GIA) (Steffen \& Wu, 2011) and background tectonic isostatic subsidence (Kooi et al., 1998) from geophysical modelling studies covering the study area.

greater amounts for older basal peats. To capture that vertical temporal effect, the trend function includes an additional linear term and a trade-off parameter $c$ to weigh this term vs. the logistic sigmoid one $(1-c)$. A second order trend surface $c$ (Eqn. 4) specifies the trade-off between the linear and sigmoidal terms. The combination of the logistic sigmoid + the linear term sums to explain the full observed GWL between lower and upper bounding envelopes. This trend function design describes steepened GWL gradients in the direction opposite to the subsidence dip (Fig. 4c) and an earlier onset and initially faster provision of accommodation space for locations with greatest total accommodation (Fig. 4d).

Towards the southwest the linear term is weighted stronger $(c=0.25)$ than towards the northeast $(c=0.17$; Fig. 4f). As a result, the sigmoid term produces moresteeply rising GWL with increasing thickness of the Holocene wedge, meaning faster inundation. Herein the GWL-index point regression-derived regionalization of this parameter reproduces Holocene differential subsidence patterns produced by geophysical glacio-isostasy (e.g. Vink et al., 2007).

\section{Execution}

The set of equations used are:

$Z n_{(x, y, t)}=\left(1-c_{(x, y)}\right) \cdot\left(1-e^{\left.-a \cdot q_{(x, y)} \cdot p_{(t)}\right)^{b}}\right)+\left(c_{(x, y)} \cdot p_{(t)}\right)$

$P(t)=\frac{\left(A_{0}-A_{(t)}\right)}{\left(A_{0}-A_{1}\right)}$

$q_{(x, y)}=\left(\frac{D_{(x, y)}}{D_{\max }}\right)$

$c_{(x, y)}=c_{0}+c_{1} x t+c_{2} y t+c_{3} x t^{2}+c_{4} x t \cdot y t+c_{5} y t^{2}$

$Z_{(x, y), t}=Z_{A 0(x, y)}+Z n_{(x, y, t)} \cdot D_{(x, y)}$ with $D_{(x, y)}=Z_{A 1(x, y)}-Z_{A 0(x, y)}$
The symbols used are:

$Z n_{(x, y, t)}$ : normalized depth (0 at lowstand; 1 at highstand); $c_{(x, y)}$ : second order trend surface on transformed coordinates $x t, y t$, with fitted parameters $c_{0}$ to $c_{5}$ (Table S2); $a, b$ : fitted parameters (Table S2); $q_{(x, y)}$ : ratio of thickness; $D_{(x, y)}$ : thickness of the coastal prism at a specific location; $D_{\max }$ : largest thickness of the coastal prism, $23.5 \mathrm{~m} ; p_{(t)}$ : normalized age $\left(0\right.$ at $A_{0}$ GWL lowstand; 1 at $A_{1}$ GWL highstand; $Z_{A 0(x, y)}$ : depth of GWL lowstand lower bound (=10 $800 \mathrm{yr}$ cal BP; $t=-10800$ ); $Z_{A 1(x, y)}$ : depth of GWL highstand upper bound (=1000 yr cal BP; $t=-1000) ; A_{0}$ : age of GWL lowstand lower bound (=10 $800 \mathrm{yr}$ cal BP; $t=-10800) ; A_{1}$ : age of GWL highstand upper bound ( $=1000 \mathrm{yr}$ cal BP; $t=-1000)$; $A_{(t)}$ : age of instance that is interpolated for $\left(A_{(t)}=-t\right)$.

The 3D grid holding the interpolation result was constructed and attributed in the Isatis ${ }^{\circledR}$ geostatistical software. Two 2D masks with an $x, y$ resolution of $1000 \times 1000 \mathrm{~m}$ covering the spatial extent of the study area, were attributed with values -1000 and -10800 respectively to obtain upper and lower bound age grids. The vertical space between the grids, expressed in age, was filled with cells with a vertical resolution of 200 years. This produced an $x, y, t$ base grid. Subsequently, as a preparation step, 3D grids with the values of the $q_{(x, y)}, p_{(t)}$ and $c$ variables were computed using Eqns. 2-4, over the spatial extent of the $x, y, t$ base grid. Then, the calculation of $Z n_{(x, y, t)}$ was conducted following Eqn. 1 and using the prepared grids. Then, a last calculation converted the normalized depth to absolute depth $z$ (Eqn. 5), making use of grids storing the lower and upper bound elevation $\left(z_{A 0(x, y)}\right.$ resp. $\left.z_{A 1(x, y)}\right)$, and the vertical thickness grid $D_{(x,}$ y) calculated from it.

To 3D kriging interpolation on the residuals to incorporate local deviations to the trend in the model was performed in Isatis ${ }^{\circledR}$ as well (kriging with external drift) (Fig. 5). The errors regarding water depth - peat type relation (see Appendix S1), where incorporated as variances of measurement errors. After the kriging procedure, the residuals were added to the $x, y, t$ trend grid, resulting in a $3 \mathrm{D}$ grid depiction regional GWL rise corrected for local deviations to the trend (Eqn. 6). 

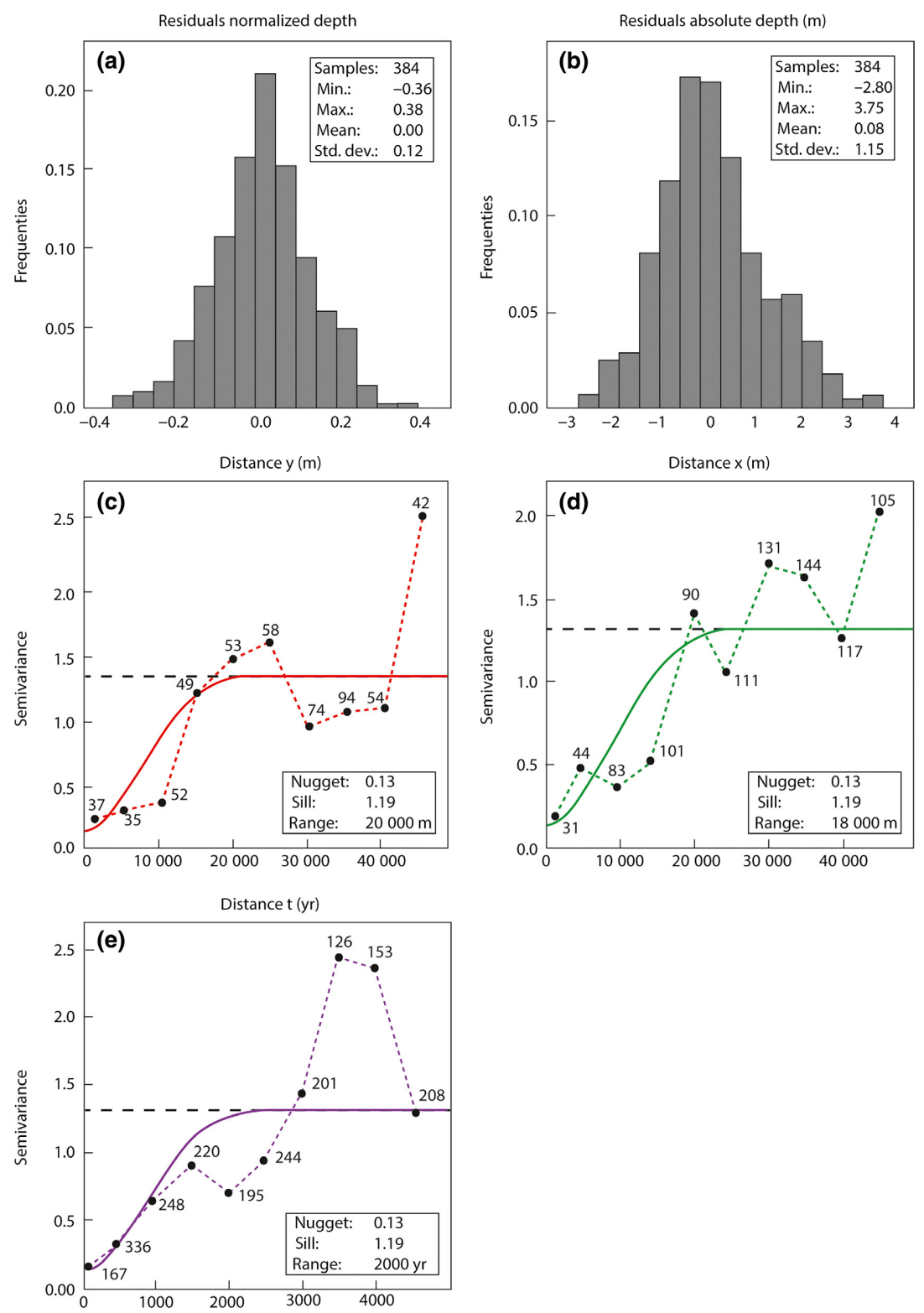

Fig. 5. Descriptive statistical information regarding the kriging part of the interpolation. (a and b) show the normal-distributed histograms of the residuals, respectively, for $Z n$ (minimized as part of the trend function regression calibration) and converted to absolute depths $z$ (that the kriging interpolation uses). (c, $\mathrm{d}$ and e) display the semi-variograms in the $x, y$ and $t$ axial directions of the 3D interpolation.

$Z_{\mathrm{KT}}=Z_{\mathrm{T}}+Z_{\mathrm{K}}$

$z_{\mathrm{KT}}$ : prediction trend with kriged residuals; $z_{\mathrm{T}}:$ trend prediction (Eqns. 1-5, grid input in Fig. 4); $z_{\mathrm{K}}$ : kriging prediction, based on $3 \mathrm{D}$ variogram model (observations in Fig. 5).

\section{Post-processing}

The post-processing steps of the 3D $x, y, t$ grid output (Fig. 6) are shown in Fig. 2c. Three types of post-processed data products were created: (i) stacked 2D surfaces, either attributed with depth or with age, (ii) GWL rise age-depth curves depicting GWL changes for specified $x, y$ location, and (iii) a resampled $3 \mathrm{D} x, y, z$ voxel grid holding age as the attribute, and therefore compatible with geological voxel models (i.e. GeoTOP).

For a cross-verification procedure of the GWL interpolation with GeoTOP, voxel model output from the latter was queried to prepare two evaluations. The first evaluation concerned comparison of GWL depths, with the depths of top fluvial sands for generations RhineMeuse delta channel belts (Berendsen \& Stouthamer, 2001; Berendsen et al., 2007b). These channel belts are well-mapped ( $c a .250000$ corings), primarily composed of sand, and a relation exists between average elevation of top of the fluvial sand (top bars in the river bed), average water levels in the river (varying through the year), and the average GWL in the flood basins between the channel belts (e.g. Makaske, 1998; Cohen, 
2005: Fig. 1; Stouthamer et al., 2011). Within GeoTOP output, channel belts are divided as five generations (Stafleu et al., 2009, 2012). The evaluation compares the elevation differences of generations 8000 $6800 \mathrm{cal} \mathrm{BP}, 6800-2500 \mathrm{cal} \mathrm{BP}$ and 2500-1000 cal BP. The second evaluation considers the drowning of the top of the Pleistocene substrate. The GeoTOP modelling of the top of the Pleistocene substrate (grid depicted in Fig. 1), was used in this evaluation. For the channel belts the output was classified into three classes: (i) younger ages, (ii) similar ages and (iii) older ages, than currently assigned within GeoTOP.

\section{RESULTS}

The GWL interpolation output documents the growth of accommodation space, defined as the increment of the water filled volume in which back-barrier sediments and peat can form potentially. Hereto we calculated accommodation space and regarded it as the volume between each consecutive 2D GWL surfaces elevated above the Pleistocene substrate, with a 200 year time interval between each GWL surface. An alternative way of looking at accommodation is to consider actual accommodation, defined by growth increment of volumetric storage of sediments (rather than water). Our interpolation output provides information regarding the evolution of accommodation space per 200 years, and includes both periods where area-averaged provision of fresh accommodation space will have exceeded (i.e. transgression, drowning) and where it will have been less than the actually accommodated volume (i.e. progradation, filling). Identifying whether actual accommodation of that created space occurred, whether it occurred simultaneously to its provision (where peat growth and sedimentation could keep up with GWL rise) or whether it was a catch-up process (Middle Holocene drowned areas that take centuries to millennia to fill in), is not part of the interpolation result. Because of the spatio-temporally diverse patterns of peat growth and tidal and fluvial sedimentation within the study area (e.g. Hijma \& Cohen, 2011; Bos et al., 2012; Vos, 2015), there is no one-on-one relation between the production of accommodation space (our method result) and actual accommodation (requiring integration with 3D geological mapping results). Our basal-peat input data set and also our cross-validation procedures make use of selected periods and subareas, where actual accommodation is considered to have caught up with accommodation space (based on the local geological understanding of setting and facies).

The overall GWL history is described as comprising of two stages, with a first stage of transgressive development with strong similarity between the two valleys, and a successive stage with strong differences between the valleys. These reconstructed GWL patterns are captured in Fig. 7a-j, which shows GWL stacked surfaces for a selection of time slices, and in Fig. 8a-d, which shows GWLcurves for a selection of sites.

At the very beginning of the considered time period, the area was still in groundwater lowstand, and over most of the area, the groundwater tables were below the top of the Pleistocene substrate (Figs $7 \mathrm{a}$ and $8 \mathrm{a}-\mathrm{d}$ ). Around 9400 cal BP, inundation of the westernmost (lowest-elevated) reaches of the valleys began (Figs $7 \mathrm{~b}$ and $8 \mathrm{a}, \mathrm{b}$ ). During subsequent centuries GWL rise accelerated (Fig. 8a, d), owing to the rapid relative sea-level change between 9000 and 8000 cal BP (Vink et al., 2007) and catalysed by stepped accelerated sea-level rise events (Hijma \& Cohen, 2010). In both palaeovalleys, this resulted in the eastward extension of the drowning area (Fig. 7c-e) and coincided in both valleys with the onset of clastic tidal deposition overlying the basal peat (Jelgersma, 1961; Hijma \& Cohen, 20110).

Around $6000 \mathrm{cal} \mathrm{BP}$, when relative sea-level and regional GWL rise were decelerating (Van de Plassche, 1982; Van de Plassche et al., 2010) (Fig. 8a-d), the lateral extent of the modern coastal plain was more or less established (Fig. 7h). Around this time, the beach barrier complex was formed and subsequent progradation of this

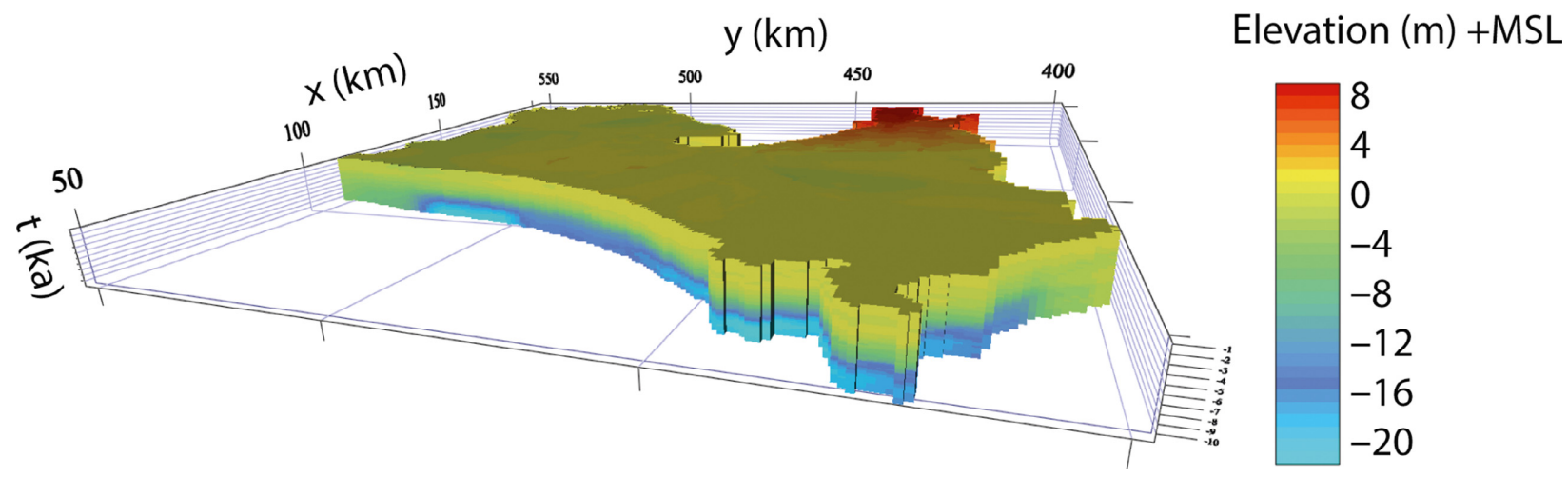

Fig. 6. Visualization of the $x, y, t$ grid. The vertical axis represents time, the cell colouring shows depth. In the vertical plane, the deep, early drowned palaeovalleys are visible by the light blue colouring at the base of the grid. Depth is seen to change greatly and rapidly in the lower part of the grid (10 000 to $5000 \mathrm{cal} \mathrm{BP} ;-20$ to $-4 \mathrm{~m})$ and not to change much in the upper part ( -4 to $0 \mathrm{~m}$, with exception of the Rhine delta affected parts). 

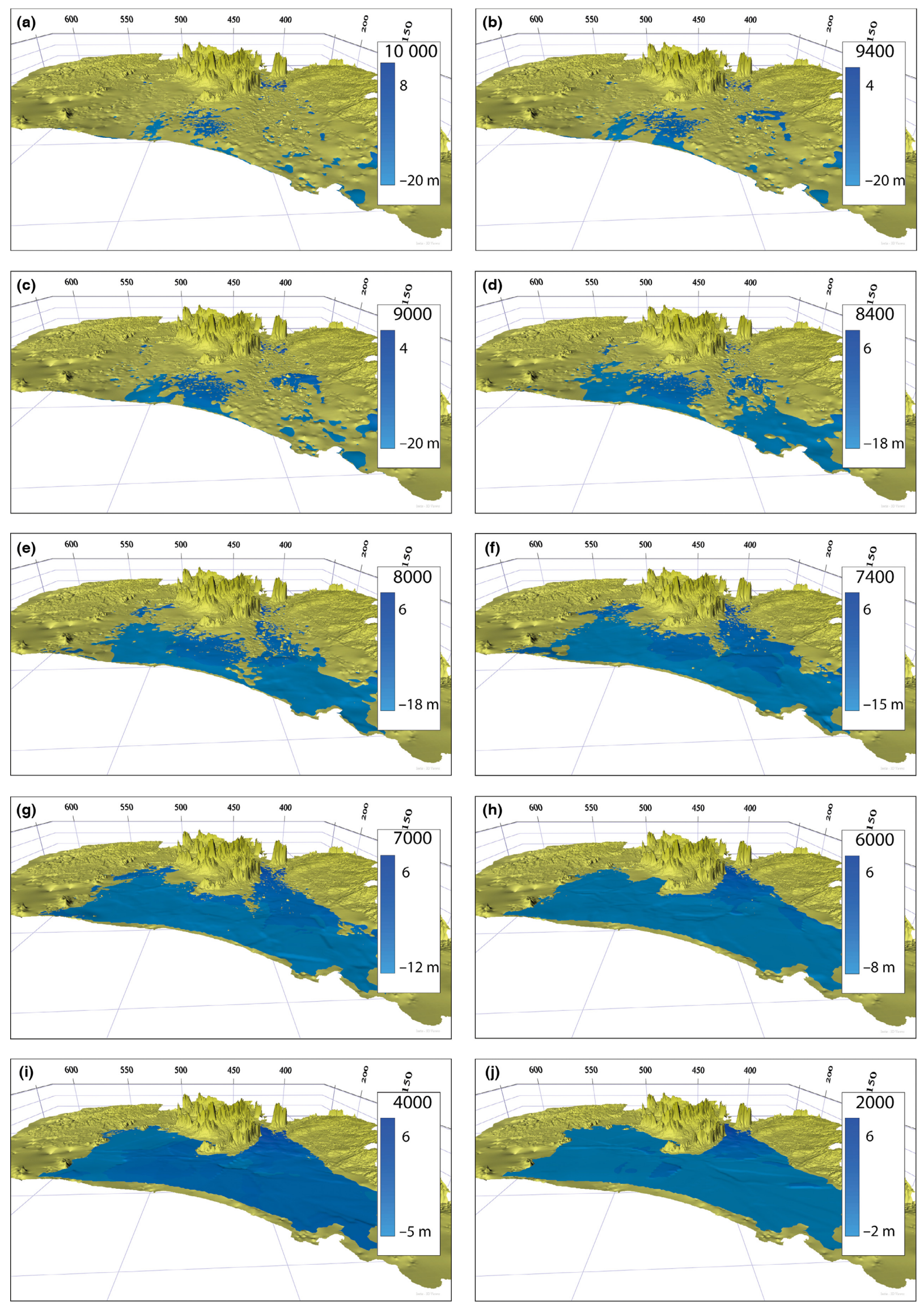

Fig. 7. (a-j) Selection of stacked surfaces at different moments in time (in yrs cal BP). The yellowish grid represents the top of the Pleistocene substrate, while the blue grid indicates areas that are inundated at a specific moment time. 

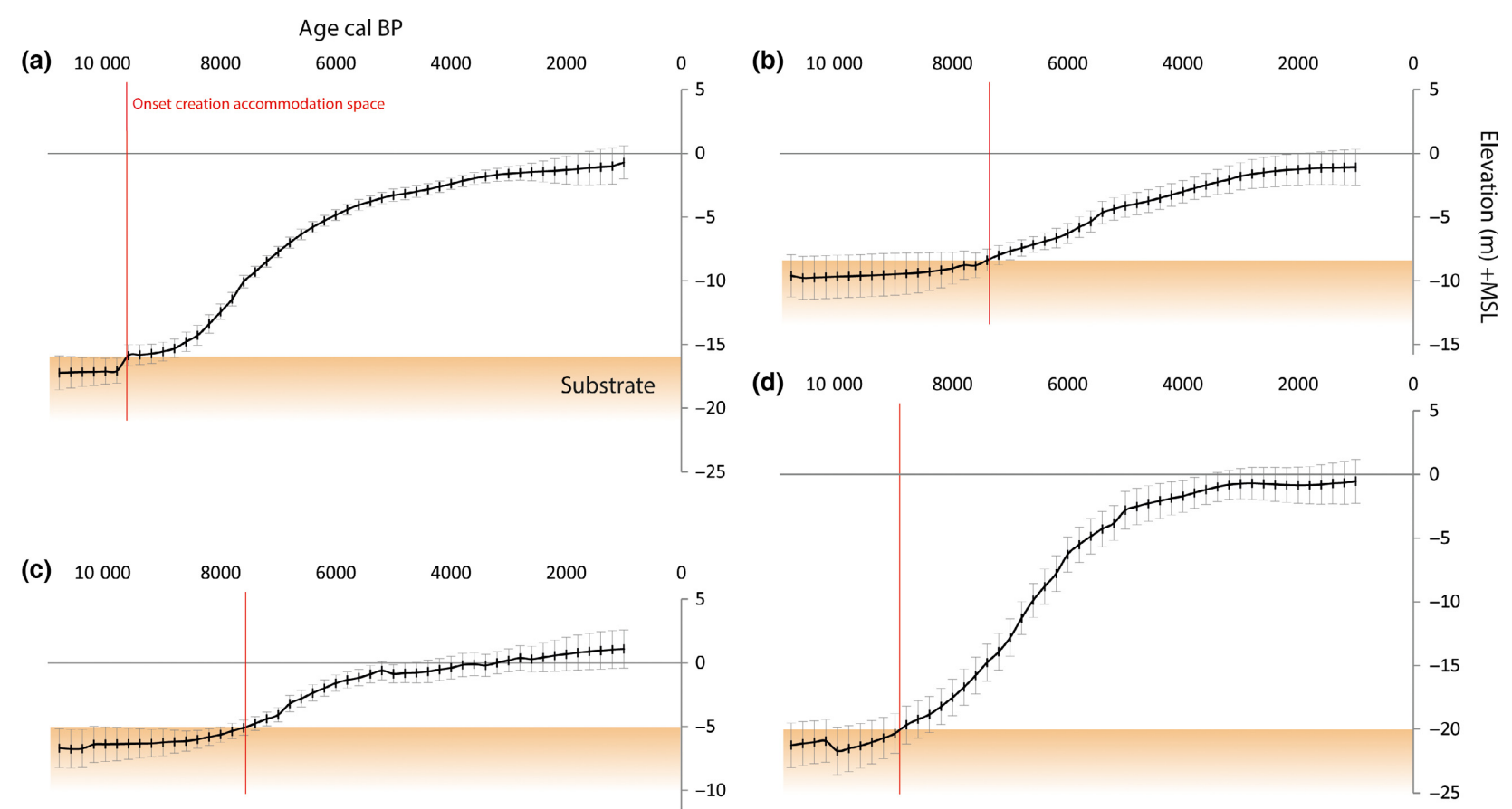

Fig. 8. (a-d) Selection of coastal groundwater levels (GWL) curves at four locations within the area. The error bands represent kriging variances, which are the product of the variograms models and errors regarding peat type - water depth, which were implemented as variances of measurement errors during interpolation. The Pleistocene substrate is indicated in orange. The red dots mark the timing of onset in aggradation. See Appendix S1 for explanation. The locations of the curves are indicated in red, in Fig. 4e.

complex set on (Beets \& Van der Spek, 2000). This did not lead to a return to more similar drowning histories of the two valleys, however, due to the influence of aggradation by the Rhine-Meuse system in the southern valley (Van Dijk et al., 1991; Törnqvist et al., 1998). The rivergradient effect in GWL is reflected in Fig. $7 \mathrm{~h}-\mathrm{j}$ by an elevated gently sloping water surface in the southern valley (darker blue colours). In the northern valley, the absence of the effect is represented by hardly sloping GWL surfaces at elevations just above MSL (lighter blue colours). Figure 8c shows the river-gradient effect in an age-depth plot of GWL rise for an inland position, which is a few metres above that in the river mouth position (Fig. 8a), where the rise of GWL approximated that of MSL (Van de Plassche, 1982). Around 5000 cal BP (Fig. 7i-j), when the beach barrier system saw most of its initial tidal inlet system to have been sanded up and inlets closed off, a vast deltaic back-barrier wetland developed, gradually aggrading under influence of background subsidence (De Mulder \& Bosch, 1982; Hijma et al., 2009).

In Fig. 9, the creation of accommodation space is summarized as line graphs, to reflect similarities and deviations in the drowning of the two palaeovalleys. During the earliest stages - up to $c a .8500$ cal BP, the creation of accommodation space is slow and hardly deviates between the two valleys. After 8500 cal BP, during the critical episode of Holocene sea-level rise that made the 'inland' part of the North Sea Basin to be the Netherlands, the respective valley drowning and accommodation histories clearly depart. In both valleys the period is characterized by a rapid increase in accommodation space, but more so in the northern valley than in the southern one. Creation of accommodation space in the northern valley stalled around 7500 cal BP, while the southern valley continued to experience an increase, eventually peaking around $6500 \mathrm{cal}$ BP. These turning points broadly coincided with stagnation of global sea-level rise, i.e. reaching modern values in far-field settings (Peltier \& Fairbanks, 2006) and marked deceleration in near-field regional sea-level rise in our study area (Kiden et al., 2002; Vink et al., 2007; Fig. 9), and the sequence-stratigraphic equivalent switch from transgressive retreating to highstand prograding in delta systems (Stanley \& Warne, 1994; Hijma \& Cohen, 2011). Provision of accommodation space from that moment onwards gradually decreased, but in the southern valley the decrease occured later and was more gradual than in the north, owing to the 'river gradient' in the groundwater table maintained in the delta plain. In valley axial direction, that gradient measures approximately $10 \mathrm{~cm} \mathrm{~km}^{-1}$ (Van Dijk et al., 1991). Similar to how the backwater effect lifts water tables in upstream direction in deltaic branching networks (Kleinhans et al., 2013), the river gradient in groundwater levels enabled base-level controlled aggradation above MSL over a distance well in-land - especially in the central deltaic area upstream of the inland tidal limits (Cohen, 2005).

The departure in inundation and creation of accommodation space between the two transgressed valleys are 


\section{K. Koster et al.}

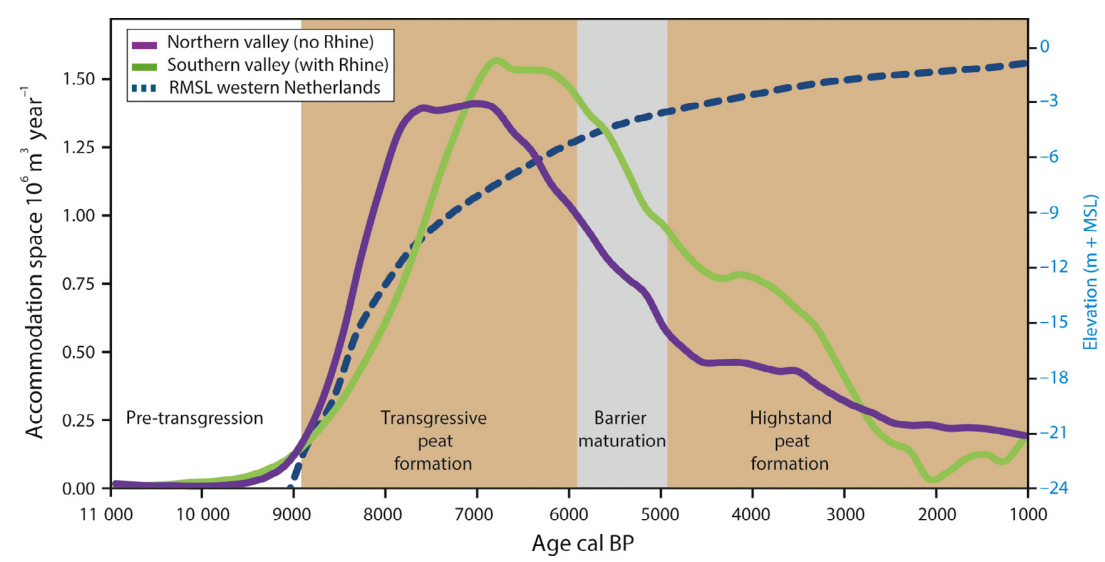

Fig. 9. Summary of the creation of accommodation space in the two palaeovalleys. Accommodation space was computed for every 200 years, for the period $10800-1000 \mathrm{cal} \mathrm{BP}$. Transgressive basal peat growth, the maturation of the barrier complex, and the subsequent formation of vast extended wetlands is also indicated. The relative mean sea-level curve for the western part of the Netherlands (Berendsen et al., 2007a; Hijma \& Cohen, 2010; Van de Plassche et al., 2010), is depicted to emphasize the relation between sea-level rise and the creation of accommodation space.

attributed to three direct causes. Firstly, the ranges and slopes of the Pleistocene substrate of both valleys differ significantly in eastern direction. Both have their lowest point around $-23.5 \mathrm{~m}$ and a slope of $c a .0 .23 \mathrm{~m} \mathrm{~km}^{-1}$. Nonetheless, the highest point of the northern valley is equal to marine highstand, thus $-0.3 \mathrm{~m}$, and that of the southern valley is at $+7 \mathrm{~m}$. This difference enabled sealevel dominated groundwater to reach far more land inward in the northern valley than in the southern one, subsequently leading to earlier inundation of the mideastern to eastern parts of the northern valley. Secondly, the northern valley during the Holocene experienced higher rates of GIA-caused subsidence (Vink et al., 2007), resulting in the creation of additional accommodation space in this valley relative to that in the south. Thirdly, the groundwater regime in the southern valleys was river dominated, inducing a gentle slope (or river gradient) elevating inland GWL above contemporary sealevel. By lack of constant feed of fresh water by a big river, river gradient effects are virtually absent in the northern valley. Effects from local river and groundwater outflow from the Pleistocene uplands surrounding the northern palaeovalley were much more modest and restricted to the very edges of the system, than the rivier gradient induced by the Rhine system. Especially when relative sea-level rise had slowed down, i.e. post $7000 \mathrm{cal} \mathrm{BP}$, this southern valley-axial gradient was responsible for creating additional accommodation space: growing a deltaic wedge that overfilled the southern valley only.

\section{Cross-verification using the GeoTOP 3D geological model}

Sedimentary levels of coastal-deltaic architectural elements are determined by GWL prevailing during their formation. The results of a comparative evaluation of GWL age-depth relations with GeoTOP-modelled tops of channel belts are shown in Fig. 10a-c. The ages assigned to the $x, y, z$ coordinates of the top-of- sand for an oldest Middle Holocene series of channel belts (Fig. 10a) are normally distributed with a mean of $7050 \mathrm{cal} \mathrm{BP}$ and a standard deviation of 500 years. This GWL-interpolation predicting age is in agreement with the geologically mapped age for these channel belts that functioned since $8000 \mathrm{cal} \mathrm{BP}$ and were abandoned prior to 6800 cal BP (Berendsen \& Stouthamer, 2001; Gouw \& Erkens, 2007; Hijma et al., 2009). The channel belt sand bodies of this oldest generation of deltaic branches, unlike younger counter parts, are in direct contact with the valley substrate, which allows neglecting post-depositional lowering of the tops of the channel belt deposits. The results along the valley axis, convincingly demonstrate that the river-induced gradient in floodbasin groundwater levels (Van Dijk et al., 1991; Vis et al., 2015), indeed resembles the gradient of the open-channel backwater effect and its fossilization in top-of-channel belts (e.g. Blum \& Törnqvist, 2000).

When the same comparative analysis is performed using younger GWL-interpolations and channel belt generations (i.e., those formed between 6800 and 2500 years BP), more differentiated patterns and dissimilarity between GWL-predicted and geological age occur. Especially in the downstream parts of the southern valley, the channel belt tops of given age are encountered at a greater depth than the interpolation derived GWL for the same age (Fig. 10b; area depicted as 'older'). This is a pattern that is expected where the top-of-sand of the channel belts today are affected by consolidation of basal Holocene strata, causing post-depositional lowering elevation of overlying channel sand (e.g., Long et al., 2006; Törnqvist et al., 2008; Van Asselen, 2011), or in the very downstream distributary reaches of the lower delta where the river loses sand and gradient lines of the top-of-sand no longer indicate former water levels (e.g. Bos \& Stouthamer, 2011). The GWL-interpolation and 

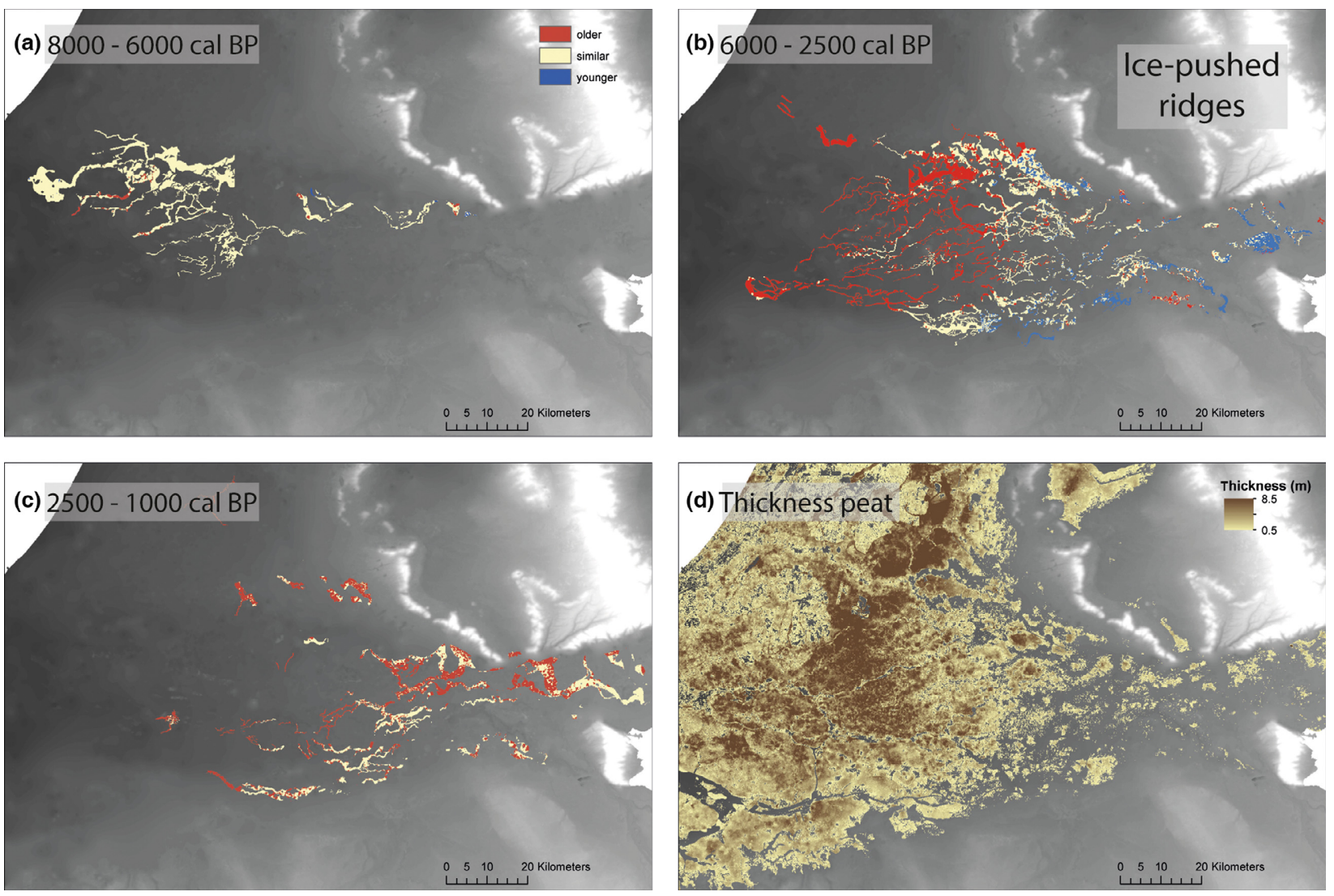

Fig. 10. The results of comparison of coastal groundwater levels (GWL) age-depth interpolations with GeoTOP channel belt agedepth. (a) For the oldest generation (8000-6000 years ago). (b) For a next younger generation (6000-2500 years ago). (c) For a younger generation (2500-1000 years ago). (d) Peat distribution of the same area. 'Younger' means: interpolated GWL age is younger than top of channel at same depth. 'Similar' means: ages are the same within dating accuracy [200 years]; 'older' means: interpolated GWL age is older than top of channel sand at same depth. Cross-verification of the four panels identifies this to be caused by consolidation of basal Holocene strata and affect younger generations of channel belts only.

geological age at top-of-sand depths are in more agreement in the upper delta and along the delta rims where post-depositional subsidence was insignificant (e.g. Makaske, 1998; Stouthamer et al., 2011).

Figure 11 shows the pattern in the timing of inundation of the Pleistocene substrate over the modelled area, i.e. when GWL had first risen to an elevation higher than the top of the substrate (compare Fig. 8: intersection of GWL rise with Top-of-Pleistocene at given locations). It shows an up-valley trend in which age decreases and marks out buried interfluve areas besides showing much local detail (such as structures of inland dune ridges in the southern valley). A remarkable newly identified feature in Fig. 11 is the relative early inundation of a great part of the major interfluve between the two palaeovalleys. This traces back to the strong local deviations of the datapoints from this area (too shallow, too old peats) from the regional trend. This could be due strong groundwaterseepage in this relatively elevated area with a complex Pleistocene substrate that connects to the aquifer systems of central Netherlands' ice-pushed ridges. Such an example shows that the incorporation of local GWL index points is essential to capture large spatiotemporal patterns.

\section{DISCUSSION}

\section{The interpolation model}

For an area of approximately $150 \times 160 \mathrm{~km}$, the datadriven interpolation summarizes and reproduces fluvial, deltaic and transgressive GWL change over a period spanning about 10000 years. This large spatial and temporal coverage inevitable requires making concessions on the sensitivity of the interpolation method. GWL rise varies due to regional and local controlling factors, which requires adequate methods for GWL reconstruction. Using the trend function approach, the focus is on those factors that operate on superregional scale, meaning that they affect vast areas over considerably long time intervals. Splitting the trend function into a linear and a logistic sigmoid part (Eqn. 1) and varying the ratio of these spatially (Eqn. 4) breaks down the description of total GWL rise into a temporally uniform component of differential subsidence across the modelled area and the time-variant components of sealevel rise and GIA. Because of this choice of trend function design, one could replace the values of the coefficients that were regression-fitted in this study with 


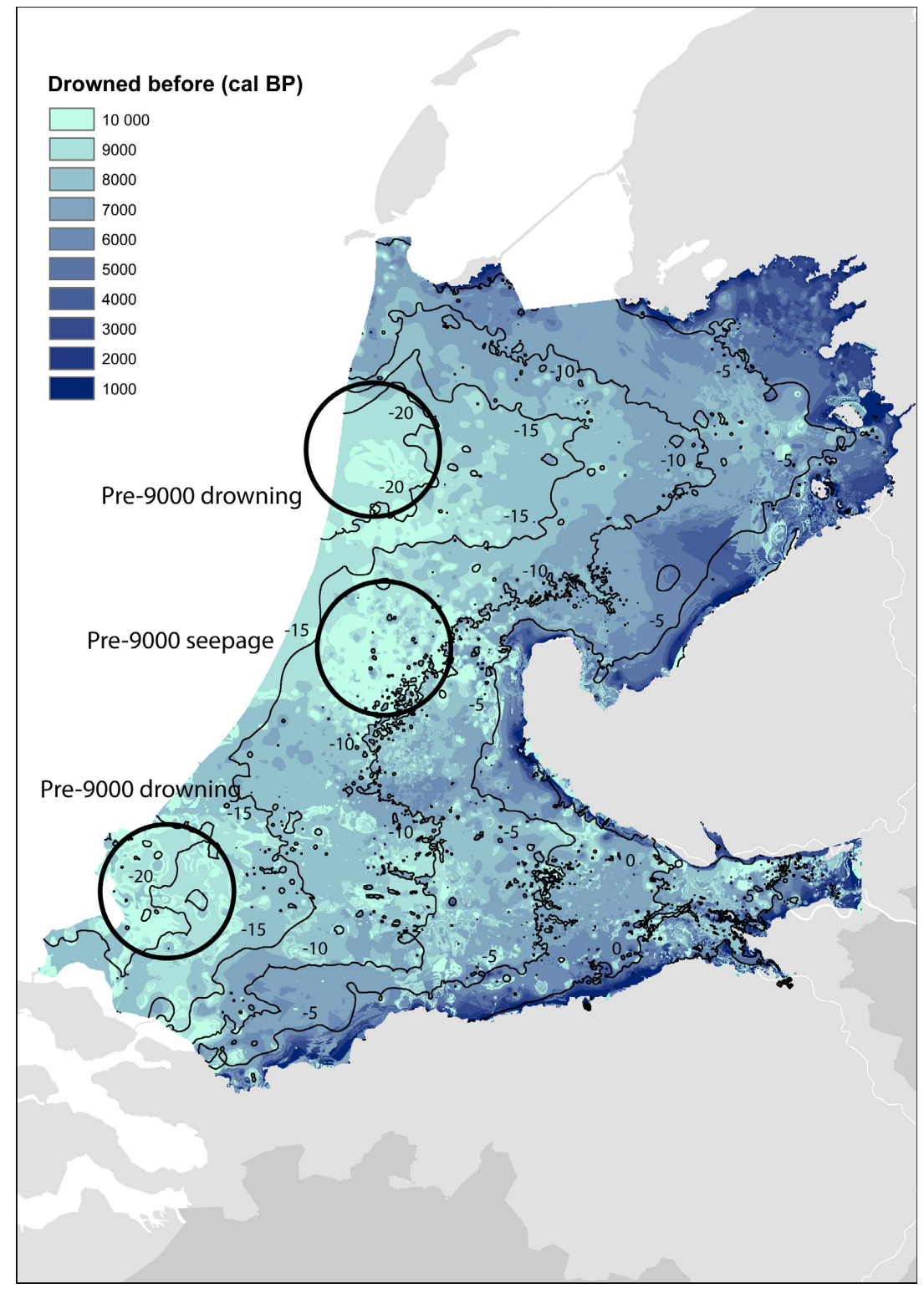

Fig. 11. The drowning of the Pleistocene substrate shows a clear west - east trend, with isolated outliers caused by local depressions and local positive topographic features. Five metre interval isolines depict the morphology of the Pleistocene substrate. The circles indicate the localities of pre- $9000 \mathrm{cal} \mathrm{BP}$ drowning of the area. In the two palaeovalleys this is driven by sea-level rise, at the interfluve this is caused by seepage deriving from higher Pleistocene grounds. alternative derived from global sea-level and/or longterm tectonic geophysical spatiotemporal model output. This offers a way to apply the trend function also in Holocene coastal wedges around the world for which direct GWL data are scarce and one has to fall back on conceptual exploration of global insights in land movement and sea-level rise, to assess provision of accommodation space in space and time. The interpolation method is only generic, however, in its covering of superregional controlling factors. Further local controls on GWL, are captured in the kriging part of the method. That is a third component, which by its design is sensitive to the availability and spatial distribution of direct data points, that is local data.

\section{Model uncertainties}

The spatial distribution of index-points is quite uneven over the study area (Fig. 4). About three-quarters of the index points were obtained in the southern valley and the rest from the north. In large areas in the northern valley, especially concentrated around its centre, index points are sparse and GWL are almost solely based on the trend function. This unequal distribution can only be overcome by denser sampling. The variances obtained after the kriging procedure will contribute to a selection strategy for optimal sampling.

In addition to the spatial distribution, also the temporal distribution of the index points could be improved. The dataset is dominated by samples ranging from 8000 to 3000 cal BP. Basal peat primarily developed during this period; therefore denser sampling will not overcome the sparse temporal distribution of basal peat. Instead, alternatives for basal peat dating that respect GWL could be incorporated, such as dendrochronological dating of bog oaks encountered in peat surfaces. The relative position of the base of a stem of known trees could act as a proper species-dependent indicator for a palaeowater level (e.g. Van der Woude, 1981). Recently, a large database composing ages and coordinates of wood excavated in the 
Netherlands obtained by dendrochronological dating has been made public (Jansma et al., 2012). A study on this database for trees e.g. drowned during the youngest stages of GWL rise in areas of clastic sedimentation instead of actual basal peat growth could potentially densify the temporal distribution (e.g. Langridge et al., 2012).

The GWL curves extracted at a selection of locations, two in the Holland coastal plain of both valleys, one in the former Zuiderzee lagoon area and one in the fluvial dominated part of the delta summarize this difference in spatiotemporal distribution of the index points (Fig. 8a-d). The standard deviation of curve sampled in the Holland coastal plain of southern valley, has minimum values of $40 \mathrm{~cm}$ around 8000 to $6000 \mathrm{cal} \mathrm{BP}$ (Fig. 8a). In contrast, the sampled curve from the northern Holland coastal plain has for that same time interval standard deviation minimum values of over $1.10 \mathrm{~m}$ (Fig. 8b). Fig. 8c, d illustrate that also in the former Zuiderzee lagoon and the fluvial dominated part of the delta, the larger standard deviations occur for the period prior to $8000 \mathrm{cal} \mathrm{BP}$ and post 3000 cal BP.

\section{Index points and hydrological control regimes}

In our reconstructions a conservative approach to inclusion of types of data-points was taken, with some types of peat dates that in more local GWL rise studies have been included, now excluded. More types of GWL indicative data-points could be considered to be included, which would then capture further local-scale GWL variation. Two examples of particular coastal plain hydrological regimes and peat-forming environments that are known to have prevailed in the study area, but had data points excluded, are the coastal-barrier beach ridge complex (Beets \& Van der Spek, 2000) and back-barrier plain raised peat bogs (Pons, 1992). According to Jelgersma et al. (1970), around $1000 \mathrm{AD}$, the water level in the centre of the kilometers-wide beach ridge complex was almost up to $4 \mathrm{~m}$ above present day MSL. This local GWL elevation affected the groundwater level on the inland side of the barrier complex, as this is indicated by the presence of mesotrophic peat developed under influence of seepage fringing the beach ridge complex (Pons \& Van Oosten, 1974; Pons, 1992). In the Late Holocene, when the barrier complex had matured (Beets \& Van der Spek, 2000), vast peat lands developed in the back-barrier area (see also Fig. 9). From approximately 3500 years ago (De Mulder \& Bosch, 1982; Gotjé, 1993), paludification in these peat lands locally began to exceed regional GWL. This means that the deltaic wetland in places transformed into oligotrophic raised bogs. These bogs were separated by mesotrophic peat brooks draining them (Pons, 1992). The GWL in these bog-draining brooks would grade to the regional GWLs as they are currently $3 \mathrm{D}$ interpolated. The local GWL in the centre of the oligotrophic domes would have been some metres (estimated $c a$. 2-4 m; e.g. Vos et al., 2015b) above the upper bounding surface that the interpolation presently uses. Direct data on the GWL in the peat domes, however, is scarce because the bogs have disappeared during the last millennium due to excavation for fuel and drainage for agricultural purposes. Very few superficial oligotrophic peats have survived reclamation and the bogs that did are found in considerably consolidated-vertically displaced position (Pons \& Van Oosten, 1974). To incorporate the local hydrological factors in the trend function would require additional terms describing the GWL in developing barrier complex and back-barrier peat bogs coastal plain, from a certain moment onwards, and for specific (disappeared-) geomorphological features that only existed at certain locations. This would have required a tailor-made approach, and most certainly would not have contributed to a generic transgression driven GWL rise modelling methodology. The age-depth information of the index points reflects prevailing GWL situations governing growth of peat. Given the sample thickness for the ${ }^{14} \mathrm{C}$-dating (centimetres), the GWL index points represent long-term (20100 year) averaged water surfaces. The trend function part of the interpolation, calibrated to the index-point data, predicts long-term change of GWL, and its parameters are designed to account for spatially variant effects of substrate topography (through parameter $q_{(x, y)}$ ), and subsidence (through parameter $\left.c_{(x, y)}\right)$. In its present form, the trend function does not explicitly deal with coastal evolutionary change, such as the development of larger tidal systems from unfilled to filled situations (e.g. Dalrymple et al., 1992) and related elevation change of GWL in near-coastal peaty environments (e.g. Van der Spek, 1994). GWL effects of tidal evolution are in play at regional scale during transgressive stage (Fig. 9), when palaeovalleys quickly drowned, whereas a sedimentary fill and the coastal barrier system took some millennia to mature (e.g. Hijma \& Cohen, 2010, 2011). That time period is well-covered by index-points (e.g. Van de Plassche, 1995; Van de Plassche et al., 2010) and in the calibration of the trend function the mean effect of this is included. The kriging-part then further optimizes the interpolation, in regions where index-point data provides. In other words, the trend function dealt implicitly with para-transgressive tidal modulation of provision of accommodation space, and can also do that when applied to other study areas.

At more local scale, tidal effects on GWL are also in play during the highstand stage (Pons, 1992; Van der Spek, 1994; Vos \& Knol, 2015; Vos et al., 2015b), when behind a matured barrier system older tidal inlets silted up and new ones formed owing to storm surge ingressions. These effects are not included in the interpolation design, input and output, neither explicitly nor implicitly. To include highstand localized tidal modification effects, one could (i) collect additional GWL index-point and use these in the kriging part of the interpolation, or (ii) add a module to the trend-function part that prescribes position, size and age of tidal inlets. The latter would require considerable additional input (tidal inlet mapping library) and it will need the index-point data to calibrate the 


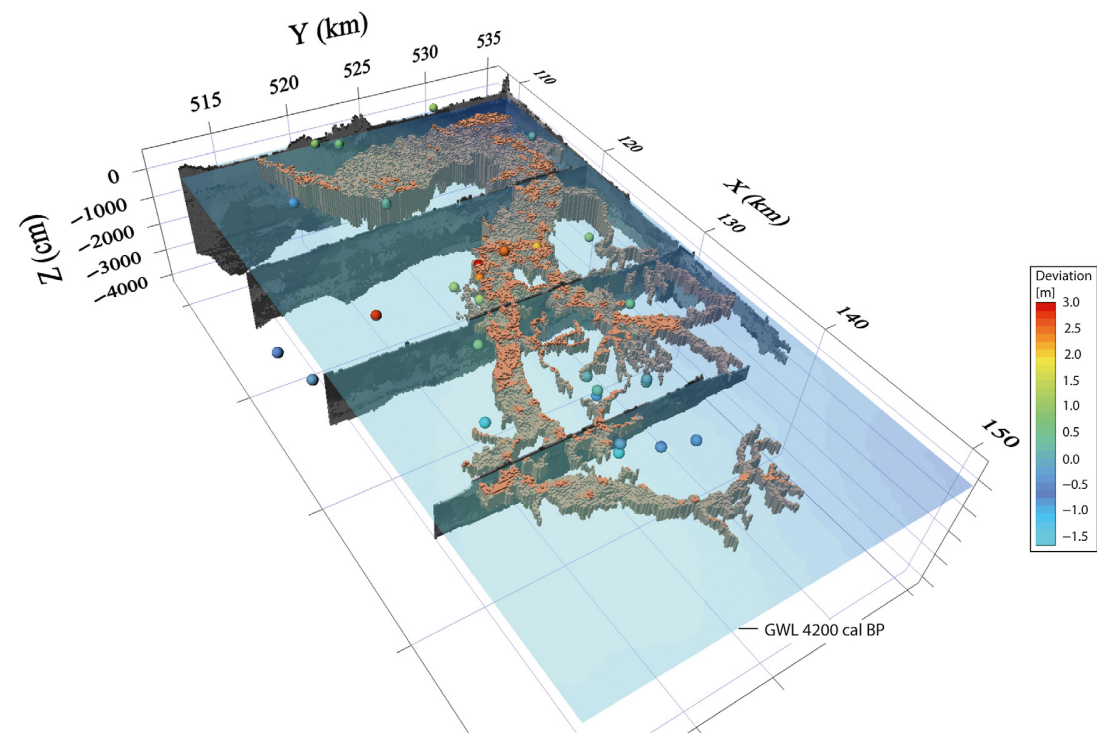

Fig. 12. A 3D fence diagram of a part of the Holocene sequence extracted from GeoTOP, with an embedded tidal inlet active from 5000 to $3500 \mathrm{cal} \mathrm{BP}$, and a 2D coastal groundwater level (GWL) of the mean age of the systems life span (see Fig. 1 for location). Non-basal peat ${ }^{14} \mathrm{C}$ datings would plot below the GWL corresponding to the time-interval of inlet activity, due to post-depositional lowering, however, the datings proximal to the inlet system plot higher than the model GWL. This discrepancy is most likely due to locally elevated GWL under influence of tidal movements during the existence of the inlet system (Van der Spek, 1994).

module's parameters. Figure 12 illustrates by comparing the current interpolation output with mapping and nonbasal peat index-point data $\left(40{ }^{14} \mathrm{C}\right.$-datings on peats overlying the Bergen tidal-inlet system in the northwest of the study area; compiled by De Mulder \& Bosch, 1982; Table S3) that data-wise it would in fact be feasible to do so for cases in the Netherlands. Indeed, the present output in areas proximal to highstand former tidal inlets for part of the time underestimates the coastal GWL by ca. $0.50-1.00 \mathrm{~m}$ (and some decimeters more if extra subsidence of the non-basal index-points is accounted for too). At greater distance from the former inlet, the extra index-points are close to the trend function predicted GWL elevations.

\section{Model applications}

The assimilation of the workflow proposed by Cohen (2005) with the high resolution geological subsurface model GeoTOP into a 3D Holocene GWL model, further improves this toolset for use in Holocene geologicalgeomorphological studies of the Rhine-Meuse delta and Holland coastal plain. An important application is that the GWL interpolation result allows to incorporate absolute age estimates in the otherwise lithological oriented 3D Holocene geological mapping products (notably: GeoTOP), as demonstrated in Figs 10-12. Modelling past water-surfaces and modelling dated sedimentary surfaces is conceptually fundamentally different, but the wealth of lithological and chronological data and system understanding reached for Holocene coastal plains, enables to connect both. Results regarding the drowning of the Pleistocene substrate could be of much importance for archaeologist interested in Neolithic and Mesolithic sites, since it provides insight regarding the need for abandonment of early habitants of certain areas (e.g. Louwe Kooijmans, 1974; Van der Woude, 1981, 1984; Vos et al., 2015a). Insights in the spatial variations of drowned landscape chronologies could contribute to a range of archaeological research interests, from prospection of potential archaeological sites to understanding drivers of past societal developments (Smith et al., 2011; Sturt et al., 2013; Cohen et al., 2014). This goes for early and middle Holocene transgressive times affecting hunter-gatherers and making their ecosystems shift, and continues in later times when farming communities used the coastal plains. The latter could experience socio-economic downfall as groundwater levels rise and crop yield diminishes. Prospection of deeply buried surfaces for archaeology is expensive and time consuming (Bates et al., 2007), but insights in GWL history can help to predict taphonomic conditions of buried surfaces and help identify archeological site sweet spots (Vos et al., 2015a). Vice-versa, archaeology could attribute to the geological aspects of GWL changes, as information regarding occupation histories of areas provide minimum drowning ages, i.e. an area was not inundated when occupied (e.g. Louwe Kooijmans, 1974; Van Dijk et al., 1991). This especially accounts for areas that are sparse in dated basal peat, but have a high concentration of archaeological finds. In our study area, however, the great amount of dated basal peat made it unnecessary to incorporate dated archaeological finds to calibrate the trend function.

Furthermore, the deviations in GWL and sedimentary ages found for the younger generations of channel belts in the peaty lower deltaic areas (Fig. 10b, c) show the potential of combined use of GWL reconstruction and geomodelling lies beyond absolute dating, and might contribute to understanding differential subsidence within deltaic and coastal settings and delta architecture in general. Discrepancy between modelled water levels and top of the channel belts is partly attributed to post-depositional consolidation of underlying organic-rich deposits by the overburden of the channel belts. Land subsidence by peat consolidation is a problem many low lying and heavily 
urbanized areas in the world are subjected to. Disentangling subsidence contributions that are naturally occurring in these settings from those induced by human activity, is a prime objective of many land subsidence studies (e.g. Tosi et al., 2013). Studying the internal deformations caused by natural peat consolidation within Holocene sequences may support understanding the drivers of subsidence within deltas, and thereby tightening the quantification of anthropogenic contributions, necessary to intervene in the process of land subsidence.

The generic approach to the trend-function design allows its application for sedimentary and/or groundwater-hydrological studies in other deltas and coastal lowlands as well. If for example this methodology would be applied in the deltas of the Piave river (northern Italy) and Mississippi river (USA), two intensively examined deltas with abundant basal peat, the lower bounding surface would be the lowest reach of oxidized pedological features in the underlying substrate (carbonate concretions in the Piave delta, Carton et al., 2009; and depth of aeration in the Mississippi delta, Törnqvist et al., 2004), lowstand-age were to be derived from peat accumulated in the deepest depressions in the substrate, and the upper bounding surface would be represented by present day elevation data (DEMs; whether corrected post-embankment sedimentation or surface lowering). Despite different densities of basal peat index-points and GIA dips in different directions - the function design would be the same, since all coastal deltas are the product of sea-level driven GWL rise and overly a substrate with valleys sloping towards the earliest inundated areas.

Furthermore, the trend function will also allow 3D GWL modelling beyond the boundaries of individual deltaic or coastal systems and nation states. For instance, the entire Holocene North Sea coastal zone ranging from Belgium to Denmark, including the deltas and estuaries of the different systems it comprises, can be captured by a recalibrated trend function. Then it can be tested how much the parameters change when compared to the values derived for the Netherlands sector alone (Table S2). Commonalities of this zone with our study area, i.e. the adjacent position of the area to the collapse of the peripheral forebulge of the Fennoscandia ice-sheet and a seaward sloping Pleistocene substrate, supports this statement. Additionally, it regards an area where many sea-level and GWL studies have been conducted, guarantying a high density of basal peat index points. Such a scale model could be deployed to support the understanding of supra-regional differences in configuration, architecture and lithological composition, and contribute to international geological big-data digital subsurface mapping projects.

\section{CONCLUSIONS}

A new 3D interpolation model for base-level rise in Holocene coastal and delta plains is presented, developed for the Netherlands. The interpolation considers former groundwater levels (GWL) in these plains as they have risen from a lowstand (just below the Pleistocene substrate) to a highstand situation (natural equivalent of modern situation) to define that accommodation. It makes use of basal peat dates as index-points to interpolate GWL surface undulations and GWL rise. This way of spatially mapping GWL and coastal plain base-levels, where data provides, in principle includes all regional factors contributing to creation of accommodation space: (i) that due to relative sea-level rise (eustasy + variable subsidence throughout the coastal plain), (ii) that due to river inflow (river gradient of inland parts of coastal plain), and (iii) that due to tidal conditions (proximal to tidal inlets). Where data is absent and the interpolation relies on its trend function part only, it covers the first and second factor.

The model covers the greater part of the Netherlands' coastal plain and contains major systems such as the rivers Rhine and Meuse, former marine areas and peatlands. It displays groundwater level rise between 10800 and 1000 cal BP and shows in high-resolution $(1000 \times 1000 \times$ 200 year or $1000 \times 1000 \times 0.5 \mathrm{~m}$ ) the drowning of two adjoining Late Pleistocene valleys - both affected by marine inundation, one with a major river delta forming. A main improvement comprised the upgrading of the trend function to deal with spatial differences in ratio of linear vs. sigmoidal terms, which was demanded by the extension of the interpolation to include a second palaeovalley, and the function design is more generic than before. The output now allows comparing the pacing of transgression and creation of accommodation of these two systems.

The 3D GWL interpolation shows strong deviations in inundation of the two examined valleys through time, due to differences in Pleistocene-inherited valley slope and the position of the Rhine delta in the Holocene. The timing of maximum provision of accommodation space differs for the two valleys. In the northern valley it peaks at ca. 7500 cal BP. In the southern valley, incremental growth of accommodation space increases until $6500 \mathrm{cal}$ BP. Thereafter, provision slows down but remains higher than the northern valley. This is due to the river gradient effect sustained by the Rhine-Meuse system.

The project was executed in the software infrastructure set up for the GeoTOP voxel model (the Netherlands' high-resolution geological model for the shallow subsurface; developed at TNO-GSN; Van der Meulen et al., 2013), and builds upon decades of data-collection by radiocarbon-dating basal peat samples and dedicated database efforts hereto (at Utrecht University; Berendsen \& Stouthamer, 2001; Cohen et al., 2012). Combined with GeoTOP, GWL 3D modelling offers a very powerful tool that enables to explicitly populate the voxel sets that make up 3D geological subsurface models with age-attributes, yielding a 4D geological mapping product.

The generic nature of the presented methodology, and especially the designed trend function, creates a major opportunity for international application of the 


\section{K. Koster et al.}

3D GWL accommodation model. Especially when 3D insight in age and depth of GWL is combined with the lithological mapping of Holocene coastal-deltaic wedges and their buried pre-transgression substrates, that enables new types of data-driven geological and/ or archaeological study at full delta and coastal plain scale.

\section{ACKNOWLEDGEMENTS}

We are thankful to thank Hans Middelkoop, Esther Stouthamer (both Utrecht University) and Freek Busschers (TNO-GSN) for their overall support and input during the conduction of this research. Furthermore, we thank Wim Hoek (Utrecht University) for sharing and discussing his palynological database regarding the Early Holocene, Hans van der Plicht (University of Groningen) for sharing metadata on ${ }^{14} \mathrm{C}$ datings executed between the 1950s and 2000, Jan Gunnink (TNO-GSN) for his advice regarding aspects of geostatistical interpolation, Patrick Kiden and Aleid Bosch (both TNOGSN) for fruitful discussions. This research is part of the PhD study of the first author, funded by TNOGSN and Utrecht University. The ${ }^{14} \mathrm{C}$ basal peat index point data used in this study is due to the combined effort of many researchers, past or present, active in the Rhine-Meuse delta and coastal plain. Special mention goes to O. van de Plassche†, H.J.A. Berendsen†, T.E. Törnqvist, P. Kiden, W. Gotjé, B. Makaske, M. van Ree, E. Stouthamer, J.H.A. Bos, M.P. Hijma, S. van Asselen and N. van Asch, whose activities greatly contributed to the dataset used here. This article benefitted greatly from reviews by Fraser Sturt, Ad van der Spek and an anonymous reviewer.

\section{CONFLICT OF INTEREST}

No conflict of interest declared.

\section{SUPPORTING INFORMATION}

Additional Supporting Information may be found in the online version of this article:

Appendix S1. Detailed information basal peat index points, upper- and lower bounding surfaces.

Fig. S1. Linear regression fitted through the plotted elevation by oxidation caused hiatuses in the Late Glacial to early Holocene organic infill of depressions (Hoek 1997b), vs. the elevation indicated by the Pleistocene substrate grid derived from GeoTOP (Fig. 1).

Table S1. Overview the ${ }^{14} \mathrm{C}$ dated basal peat index points used for the interpolation.

Table S2. Calibrated parameter values obtained after trend fitting.
Table S3. Overview the ${ }^{14} \mathrm{C}$ dated intercalated peat used for Fig. 12.

\section{REFERENCES}

Bates, M.R., Bates, C.R. \& Whittaker, J.E. (2007) Mixed method approach to the investigation and mapping of buried Quaternary deposits: examples from southern England. Archaeol. Prospect., 14(2), 104-129.

Beets, D.J. \& Van der SpeK, A.J.F. (2000) The Holocene evolution of the barrier and back-barrier basins of Belgium and the Netherlands as a function of late Weichselian morphology, relative sea-level rise and sediment supply. Neth. F. Geosci, 79, 3-16.

BeHre, K.E. (2007) A new Holocene sea-level curve for the southern North Sea. Boreas, 36(1), 82-102.

Bennema, J. (1954) Holocene movements of land- and sea-level in the coastal area of the Netherlands. Geol. Mijnboum, 16, 254-264.

Berendsen, H.J.A. \& Stouthamer, E. (2001) Palaeogeographic Development of the Rhine-Meuse Delta, The Netherlands. Van Gorcum, Assen.

Berendsen, H.J.A., Makaske, B., Van de Plassche, O., Van Ree, H.M.H., Das, S., Van Dongen, M., Ploumen, S. \& Schoenmakers, W. (2007a) New groundwater-level rise data from the Rhine-Meuse delta - implications for the reconstruction of Holocene relative mean sea-level rise and differential land-level movements. Neth. F. Geosci., 86, 333-354.

Berendsen, H.J.A., Cohen, K.M. \& Stouthamer, E. (2007b) The use of GIS in reconstructing the Holocene palaeogeography of the Rhine-Meuse delta, The Netherlands. Int. 7 . Geogr. Inf. Sci., 21, 589-602.

Blum, M.D. \& Törnqvist, T.E. (2000) Fluvial responses to climate and sea-level change: a review and look forward. Sedimentology, 47, 2-48.

Blum, M.D., Tomkin, J.H., Purcell, A. \& Lancaster, R.R. (2008) Ups and downs of the Mississippi Delta. Geology, 36 (9), 675-678.

BORGER, G.J. (1992) Draining-digging-dredging; the creation of a new landscape in the peat areas of the low countries. In: Fens and Bogs in the Netherlands: Vegetation, History, Nutrient Dynamics and Conservation (Ed. by J.T.A. Verhoeven) Geobotany, 18, 131-172

Bos, I.J. \& Stouthamer, E. (2011) Spatial and temporal distribution of sand-containing basin fills in the Holocene RhineMeuse delta, the Netherlands. F. Geol., 119, 641-660.

Bos, J.A.A., Van Geel, B., Van der Plicht, J. \& Bohncke, S.J.P. (2007) Preboreal climate oscillations in Europe: wigglematch dating and synthesis of Dutch high-resolution multiproxy records (Ed. by W.Z. Hoek \& J.A.A. Bos). Quatern. Sci. Rev., 26(15-16), 1927-1950.

Bos, I.J., Busschers, F.S. \& Hoek, W.Z. (2012) Organic-facies determination: a key for understanding facies distribution in the basal peat layer of the Holocene Rhine-Meuse delta, the Netherlands. Sedimentology, 59(2), 676-703.

Bronk Ramsey, C. (2009) Dealing with outliers and offsets in Radiocarbon dating. Radiocarbon, 51(3), 1023-1045.

Busschers, F.S., Kasse, C., Van Balen, R.T., Vandenberghe, J., Cohen, K.M., Weerts, H.J.T., Wallinga, J., Johns, C., Cleveringa, P. \& Bunnik, F.P.M. (2007) Late Pleistocene 
evolution of the Rhine-Meuse system in the southern North Sea basin: imprints of climate change, sea-level oscillation and glacio-isostacy. Quatern. Sci. Rev., 26, 3216-3248.

Busschers, F.S., Van Balen, R.T., Cohen, K.M., Kasse, C., Weerts, H.J.T., Wallinga, J. \& Bunnik, F.P.M. (2008) Response of the Rhine-Meuse fluvial system to Saalian icesheet dynamics. Boreas, 37, 377-398.

Carton, A., Bondesan, A., Fontana, A., Meneghel, M., Miola, A., Mozzi, P., Primon, S. \& Surian, N. (2009) Geomorphological evolution and sediment transfer in the Piave River system (northeastern Italy) since the Last Glacial Maximum. Géomorphologie, 3, 155-174.

Cohen, K.M. (2003) Differential subsidence within a coastal prism. Late-Glacial - Holocene tectonics in the Rhine-Meuse delta, the Netherlands. PhD dissertation, Utrecht University, Netherlands Geographical Studies 316.

CoHEN, K.M. (2005) 3D geostatistical interpolation and geological interpretation of paleo-groundwater rise in the Holocene coastal prism in the Netherlands. In: River Deltas - Concepts, Models, and Examples (Ed. by L. Giosan \& J.P. Bhattacharya), SEPM Special Publication, 83, 341-364

Cohen, K.M., Stouthamer, E. \& Berendsen, H.J.A. (2002) Fluvial deposits as a record for neotectonic activity in the Rhine-Meuse delta, the Netherlands. Neth. 7. Geosci., 81, 389-405.

Cohen, K.M., Gouw, M.J.P. \& Holten, J.P. (2005) Fluvio-deltaic floodbasin deposits recording differential subsidence within a coastal prism (central Rhine-Meuse delta, the Netherlands). Fuvial Sedimentology VII, 7th International Conference on Fluvial Sedimentology Lincoln Nebraska USA, Blackwell, 295-320.

Cohen, K.M., Stouthamer, E., Pierik, H.J. \& Geurts, A.H. (2012) Digitaal Basisbestand Paleogeografie van de Rijn-Maas Delta/Rhine-Meuse Delta Studies' Digital Basemap for Delta Evolution and Palaeogeography. Dept. Physical Geography. Utrecht University. Digital Dataset. DANS. http:// dx.doi.org/10.17026/dans-x7g-sjtw.

Cohen, K.M., Gibbard, P.L. \& WeErts, H.J.T. (2014) North Sea palaeogeographical reconstructions for the last $1 \mathrm{Ma}$. Neth. 7. Geosci., 93, 7-29.

Crombé, P., Verhegge, J., Deforce, K., Meylemans, E. \& Robinson, E. (2015) Wetland landscape dynamics, Swifterbant land use systems, and the Mesolithic-Neolithic transition in the southern North Sea basin. Quatern. Int., 378, 119-133.

Dalrymple, R.W., Zaitlin, B.A. \& Boyd, R. (1992) Estuarine facies models: conceptual basis and stratigraphic implications: perspective. 7. Sediment. Petrol., 62, 1130-1146.

De BonT, C. (2015) Digging the river: the historical geography of the Amstel area (800-1275). Neth. F. Geosci., 94, 333-352.

De Mulder, E.F.J. \& Bosch, J.H.A. (1982) Holocene stratigraphy, radiocarbon datings and paleogeography of Central and Northern North-Holland (The Netherlands), Med. van de Rijks Geol. Dienst, 36-3, 111 - 160de milder.

Denys, L. \& Baeteman, C. (1995) Holocene evolution of relative sea level and local mean high water spring tides in Belgium - a first assessment. Mar. Geol., 124, 1-19.

Fontana, A., Mozzi, P. \& Bondesan, A. (2008) Alluvial megafans in the Venetian-Friulian Plain (north-eastern Italy): evidence of sedimentary and erosive phases during Late Pleistocene and Holocene. Quatern. Int., 189(1), 7190.

Gehrels, W.R., Szkornik, K., Bartholdy, J., Kriby, J.R., Bradley, S.L., Marshall, W.A., Heinemeier, J. \&
Pedersen, J.B.T. (2006) Late Holocene sea-level changes and isostasy in western Denmark. Quatern. Res., 66(2), 288-302.

Goтjé, W. (1993) De Holocene laagveenontwikkeling in de randzone van de Nederlandse kustvlakte (Noordoostpolder) (in Dutch). Unpublished PhD dissertation, VU University Amsterdam.

Gouw, M.J.P. \& Erkens, G. (2007) Architecture of the Holocene Rhine-Meuse delta (the Netherlands): a result of changing external controls. Neth. 7. Geosci., 86, 23-54.

Hanebuth, T.J.J., Proske, U., Saito, Y., Nguyen, V.L. \& OANH TA, T.K. (2012) Early growth stage of a large delta transformation from estuarine-platform to deltaic-progradational conditions (the northeastern Mekong River Delta, Vietnam). Sed. Geol., 261-262, 108-119.

HiJMA, M.P. \& COHEN, K.M. (2010) Timing of and magnitude of the sea-level jump preluding the $8200 \mathrm{yr}$ event. Geology, $38,275-278$.

Hijma, M.P. \& CoHEN, K.M. (2011) Holocene transgression of the Rhine river mouth area, the Netherlands/Southern North Sea: palaeogeography and sequence stratigraphy. Sedimentology, 58, 1453-1485.

Hijma, M.P., Cohen, K.M., Hoffmann, G., Van der Spek, A.J.F. \& Stouthamer, E. (2009) From river valley to estuary: the evolution of the Rhine mouth in the early to middle Holocene (western Netherlands, Rhine-Meuse delta). Neth. F. Geosci., 88(1), 13-53.

Hijma, M.P., Cohen, K.M., Roebroeks, W., Westerhoff, W.E. \& Busschers, F.S. (2012) Pleistocene Rhine-Thames landscapes: geological background for hominin occupation of the southern North Sea region. 7. Quat. Sci., 27, 17-39.

Hoek, W.Z. \& Bohncke, S.J.P. (2002) Climatic and environmental events over the last termination, as recorded in the Netherlands: a review. Neth. F. Geosci., 81, 123-137.

Hoffmann, T., Erkens, G., Cohen, K.M., Houben, P., Seidel, J. \& DiKaU, R. (2007) Holocene floodplain sediment storage and hillslope erosion within the Rhine catchment. Holocene, $17,105-118$.

Hori, K. \& Saito, Y. (2007) An early Holocene sea-level jump and delta initiation. Geophys. Res. Lett., 34, 1-5.

Jansma, E., Van Lanen, R.J., Brewer, P.W. \& Kramer, R. (2012) The DCCD: a digital data infrastructure for tree-ring research. Dendrochronologia, 30(4), 249-251.

Jelgersma, S. (1961) Holocene sea level changes in the Netherlands. PhD dissertation Leiden University, Med. van de Rijks Geol. stichting, serie C.

Jelgersma, S. (1979) Sea level changes in the North Sea Basin. In: The Quaternary History of the North Sea (Ed. by E. Oele), pp. 233-248. University of Uppsala, Borgströms tryckeri, Motala, Sweden.

Jelgersma, S., De Jong, P., Zagwijn, W.H. \& Van Regteren Altena, J.F. (1970) The coastal dunes of the Western Netherlands: geology, vegetational history and archaeology. Med. van de Rijks Geol. Dienst, 21, 93-167.

KIDEN, P. (1995) Holocene relative sea-level change and crustal movement in the southwestern Netherlands. Mar. Geol., 124, $21-41$.

Kiden, P., Denys, L. \& Johnston, P. (2002) Late Quaternary sea-level change and isostatic and tectonic land movements along the Belgian-Dutch North Sea coast: geological data and model results. F. Quat. Sci., 17, 535-546.

Kleinhans, M.G., Ferguson, R.I., Lane, S.N. \& Hardy, R.J. (2013) Splitting rivers at their seams: bifurcations and avulsions. Earth Surf. Proc. Land., 38, 47-61. 
Kooi, H., Johnston, P., Lambeck., K., Smither, C. \& MolenDIJK, R. (1998) Geological causes of recent ( $100 \mathrm{yr})$ vertical land movement in the Netherlands. Tectonophysics, 299, 297316.

LAMBECK, K. (1997) Sea-level change along the French Atlantic and Channel coasts since the time of the Last Glacial Maximum. Palaeogeogr. Palaeoclimatol. Palaeoecol., 129, 1-22.

Lambeck, K. \& Purcell, A. (2005) Sea-level change in the Mediterranean Sea since the LGM: model predictions for tectonically stable areas. Quatern. Sci. Rev., 24, 1969-1988.

LAMBECK, K., Johnston, P. \& NAKADA, M. (1990) Holocene glacial rebound and sea-level change in NW Europe. Geophys. 7 . Int., 103, 451-468.

Langridge, R.M., Basili, R., Basher, L. \& Wells, A.P. (2012) Late Holocene landscape change history related to the Alpine fault determined from drowned forest in Lak Poera, Westland, New Zealand. Nat. Hazard. Earth Syst. Sci., 12, 20512064.

Long, A.J., Waller, M.P. \& Stupples, P. (2006) Driving mechanisms of coastal change: peat compaction and the destruction of late Holocene coastal wetlands. Mar. Geol., $225,63-84$.

Louwe Koojjmans, L.P. (1974) The Rhine/Meuse Delta: four studies on its prehistoric occupation and Holocene geology. $\mathrm{PhD}$ dissertation, University of Leiden.

MaKaske, B. (1998) Anastomosing rivers. Forms, processes and sediments. PhD dissertation, Utrecht University, Netherlands Geographical Studies 249.

Makaske, B., Van Smeerdijk, D.G., Peeters, H., Mulder, J.R. \& SPEK, T. (2003) Relative water-level rise in the Flevo lagoon (the Netherlands), 5300-2300 cal. yr. BC: an evaluation of new and existing basal peat time-depth data. Neth. F. Geosci., $82,115-131$.

Maljers, D., Stafleu, J., Van der Meulen, M.J. \& Dambrink, R.M. (2015) Advances in constructing regional geological voxel models, illustrated by their application in aggregate resource assessments. Neth. F. Geosci., 94, 257-270.

Peeters, J., Busschers, F.S. \& Stouthamer, E. (2015) Fluvial evolution of the Rhine during the last interglacial-glacial cycle in the southern North Sea basin: a review and look forward. Quatern. Int., 357, 176-188.

Peeters, J., Busschers, F.S., Stouthamer, E., Bosch, J.H.A., Van den Berg, M.W., Wallinga, J., Versendaal, A.J., BunNIK, F.P.M. \& MidDELKoop, H. (2016) Sedimentary architecture and chronostratigraphy of a late Quaternary incisedvalley fill: a case study of the late Middle and Late Pleistocene Rhine system in the Netherlands. Quatern. Sci. Rev., 131, 211-236.

Peltier, W.R. \& Fairbanks, R.G. (2006) Global glacial ice volume and Last Glacial Maximum duration from an extended Barbados sea level record. Quatern. Sci. Rev., 25, 3322-3337.

Pons, L.J. (1992) Holocene peat formation in the lower parts of the Netherlands. In: Fens and Bogs in the Netherlands: Vegetation, History, Nutrient Dynamics and Conservation (Ed. by J.T.A. Verhoeven), Geobotany, 18, 7-80.

Pons, L.J. \& Van Oosten, H.F. (1974) De bodem van NoordHolland. Toelichting bij blad 5 van de bodemkaart van Nederland 1:200.000 (in Dutch). Stichting voor Bodemkartering, Wageningen.

Reimer, P.J., Bard, E., Bayliss, A., Beck, J.W., Blackwell, P.G., Bronk Ramsey, C., Buck, C.E., Cheng, H., Edwards, R.L., Friedrich, M., Grootes, P.M., Guilderson, T.P., Haflidason, H., Hajdas, I., Hatté, C., Heaton, T.J.,
Hoffmann, D.L., Hogg, A.G., Hughen, K.A., Kaiser, K.F., Kromer, B., Manning, S.W., Niu, M., Reimer, R.W., Richards, D.A., Scott, E.M., Southon, J.R., StafF, R.A., Turney, C.S.M. \& Plicht, J.V.D. (2013) IntCal13 and Marine13 radiocarbon age calibration curves $0-50,000$ years cal BP. Radiocarbon, 55, 1869-1887.

Smith, D.E., Harrison, S., Firth, C.R. \& Jordan, J.T. (2011) The early Holocene sea level rise. Quatern. Sci. Rev., 30, 1846-1860.

Stafleu, J., Busschers, F.S., Maljers, D. \& Gunnink, J.L. (2009) Three-dimensional property modeling of a complex fluvio-deltaic environment: Rhine-Meuse Delta, the Netherlands. In: Workshop Extended Abstracts of the 2009 Annual Meeting, Geological Society of America, October 17 2009, Portland, Oregon, USA (Ed. by R.C. Berg, H.A.J. Russel \& L.H. Thorleifson), 47-50.

Stafleu, J., Maljers, D., Gunnink, J.L., Menkovic, A. \& Busschers, F.S. (2011) 3D modelling of the shallow subsurface of Zeeland, the Netherlands. Neth. 7. Geosci., 90, 293310 .

Stafleu, J., Maljers, D., Busscher, F.S., Gunnink, J.L., Schokker, J., Dambrink, R.M., Hummelman, H.J. \& Schijf, M.L. (2012) GeoTOP modellering (in Dutch). TNO Report R10991, 1-216.

Stanley, D.J. \& Warne, A.G. (1994) Worldwide initiation of Holocene marine deltas by deceleration of sea-level rise. Science, 265, 228-231.

Steffen, H. \& Wu, P. (2011) Glacial isostatic adjustment in Fennoscandia - a review of data and modelling. F. Geodyn., 52(3-4), 169-204.

Stouthamer, E., Cohen, K.M. \& Gouw, M.J.P. (2011) Avulsion and its implication for fluvial-deltaic architecture: insights from the Holocene Rhine-Meuse delta. In: From River to Rock Record: The Preservation of Fluvial Sediments and their Subsequent Interpretation (Ed. by S.K. Davidson, S. Leleu \& C.P. North), Society for Sedimentary Geology Special Publication, 97, 215-231.

STREIF, H. (2004) Sedimentary record of Pleistocene and Holocene marine inundations along the North Sea coast of Lower Saxony, Germany. Quatern. Int., 112, 3-28.

Sturt, F., Garrow, D. \& Bradley, S. (2013) New models of Nort West European Holocene palaeogeography and inundation. F. Archaeol. Sci., 40, 3963-3976.

Tanabe, S., Nakanishi, T., Ishihara, Y. \& Nakashima, R. (2015) Millennial-scale stratigraphy of a tide-dominated incised valley during the last $14 \mathrm{kyr}$ : spatial and quantitative reconstruction in the Tokyo Lowland, central Japan. Sedimentology, 62, 1837-1872.

Törnqvist, T.E., Van Ree, M.H.M., Van 'T Veer, R. \& Van GeEL, B. (1998) Improving methodology for high-resolution reconstruction of sea-level rise and neotectonics by paleoecological analysis and AMS ${ }^{14} \mathrm{C}$ dating of basal peat. Quatern. Res., 49, 72-85.

Törnqvist, T.E., González, J.L., Newsom, L.A., Van der Borg, K., De Jong, A.F.M. \& Kurnik, C.W. (2004) Deciphering Holocene sea-level history on the U.S. Gulf Coast: a high resolution record rom the Mississippi delta. Geol. Soc. Am. Bull., 116, 1026-1039.

Törnqvist, T.E., Wallace, D.J., Storms, J.E.A., Wallinga, J., Van Dam, R.L., Blaauw, M., Derksen, M.S., Klerks, C.J.W., Meijneken, C. \& Snijders, E.M.A. (2008) Mississippi Delta subsidence primarily caused by compaction of Holocene strata. Nat. Geosci., 1, 173-176. 
Tosi, L., Teatini, P. \& Strozzi, T. (2013) Natural versus anthropogenic subsidence of Venice. Sci. Rep., 3, 2710.

Tropeano, M., Cilumbriello, A., Sabato, L., Gallichio, S., Grippa, A., Longhitano, S.G., Bianca, M., Gallipoli, R., Mucciarelli, M. \& Spilotro, G. (2013) Surface and subsurface of the Metaponto Coastal Plain (Golf of Taranto - southern Italy): present-day- vs LGM-landscape. Geomorphology, 203, 115-131.

Van Asselen, S. (2011) The contribution of peat compaction to total basin subsidence: implications for the provision of accommodation space in organic-rich deltas. Basin Res., 23, 239-255.

Van Balen, R.T., Houtgast, R.F. \& Cloetingh, S.A.P.L. (2005) Neotectonics of the Netherlands: a review. Quatern. Sci. Rev., 24, 439-454.

Van de Plassche, O. (1982) Sea-level change and water-level movements in the Netherlands during the Holocene. PhD dissertation, VU University Amsterdam, Med. Rijks Geol. Dienst.

Van de Plassche, O. (1995) Evolution of the intra-coastal tidal range in the Rhine-Meuse delta and Flevo Lagoon, 57003000 yrs cal BC. Mar. Geol., 124, 113-128.

Van de Plassche, O., Makaske, B., Hoek, W.Z., Konert, M. \& Van der Plicht, J. (2010) Mid-Holocene water-level changes in the lower Rhine-Meuse delta (western Netherlands): implications for the reconstruction of relative mean sea-level rise, palaeoriver-gradients and coastal evolution. Neth. 7. Geosci., 89, 3-20.

Van der Meulen, M.J., Doornebal, J.C., Gunnink, J.L., Stafleu, J., Schokker, J., Vernes, R.W., Van Geer, F.C., Van Gessel, S.F., Van Heteren, S., Van Leeuwen, R.J.W., BaKKer, M.A.J., Bogatard, P.J.F., Busschers, F.S., Griffioen, J., Grujters, S.H.L.L., Kiden, P., Schroot, B.M., SimMelink, H.J., Van Berkel, W.O., Van der Krogt, R.A.A., Westerhoff, W.E. \& Van Daalen, T.M. (2013) 3D geology in a 2D country: perspectives for geological surveying in the Netherlands. Neth. 7. Geosci., 92, 217-241.

Van der Molen, J. \& De Swart, H.E. (2001) Holocene tidal conditions and tide-induced sand transport in the southern North Sea. 7. Geophys. Res., 106(C5), 9339-9362.

VAN DER SPEK, A.J.F. (1994) Large-scale evolution of Holocene tidal basins in the Netherlands. PhD dissertation, Utrecht University.

Van der Spek, A.J.F., Stive, M. \& Zitman, T. (2001) Ebb and Flood Channel Systems in the Netherlands Tidal Waters. Reprint of original Dutch text of Van Veen (1950) with English translations and annotations. Department of Hydraulic Engineering, Delft University of Technology. $61 \mathrm{pp}$.

VAN DER WOUDE, J.D. (1981) Holocene paleoenvironmental evolution of a perimarine fluvialtile area. $\mathrm{PhD}$ dissertation, $\mathrm{VU}$ University Amsterdam.

VAN DER WOUDE, J.D. (1984) The fluviolagoonal palaeoenvironment in the Rhine/Meuse deltaic plain. Sedimentology, 31, 395-400.
Van Dijk, G.J., Berendsen, H.J.A. \& Roeleveld, W. (1991) Holocene water level development in the Netherlands' river area; implications for sea-level reconstruction. Geol. Mijnboum, 70, 311-326.

Van Straaten, L.M.J.U. (1954) Radiocarbon datings and changes of sea level at Velsen (the Netherlands). Geol. Mijnboum, 16, 247-253.

Van VEEN, J. (1950) Eb-en vloedschaar systemen in de Nederlandse getijwateren (in Dutch). Geogr. Tydschr., 67, 43-65.

Vella, C. \& Provansal, M. (2000) Relative sea-level rise and neotectonic events during the last $6500 \mathrm{yr}$ on the southern eastern Rhône delta, France. Mar. Geol., 170, 27-39.

Vink, A., Steffen, H., Reinhardt, L. \& Kaufmann, G. (2007) Holocene relative sea-level change, isostactic subsidence and the radial viscosity structure of the mantle of northwest Europe (Belgium, the Netherlands, Germany, southern North Sea). Quatern. Sci. Rev., 26(25-28), 32493275.

Vis, G.J., Westerhoff, W.E., Ten Veen, J.H., Hijma, M.P., VAn Der SpeK, A.J., Vos, P.C. \& Cohen, K.M. (2015) Chapter 33: Paleogeography. In: Handbook of Sea-Level Research (Ed. by I. Shennan, A.J. Long \& P.H. Horton), pp. 600. Wiley-Blackwell, American Geophysical Union, Hoboken.

Vos, P.C. (2015) Origin of the Dutch coastal landscape. Longterm landscape evolution of the Netherlands during the Holocene, described and visualized in national, regional and local palaeogeographical map series. $\mathrm{PhD}$ dissertation, Utrecht University, Barkhuis Groningen.

Vos, P.C. \& KNOL, E. (2015) Holocene landscape reconstruction of the Wadden Sea area between Marsdiep and Weser. Neth. 7. Geosci., doi:10.1017/njg.2015.4.

Vos, P.C., Bunnik, F.P.M., Cohen, K.M. \& Cremer, H. (2015a) A staged geogenetic approach to underwater archaeological prospection in the Port of Rotterdam (Yangtzehaven, Maasvlakte, The Netherlands): a geological and palaeoenvironmental case study for local mapping of Mesolithic lowlands landscapes. Quatern. Int., 367, 4-31.

Vos, P.C., de Koning, J. \& Van Eerden, R. (2015b) Landscape history of the Oer-IJ tidal system, Noord-Holland (the Netherlands). Neth. F. Geosci., 94, 295-332.

Wang, Z., Zhan, Q., Long, H., Saito, Y., GaO, X., Wu, X., LI, L. \& Zнао, Y. (2013) Early to mid-Holocene rapid sea-level rise and coastal response on the southern Yangtze delta plain, China. 7. Quat. Sci., 28, 659-672.

Zagwijn, W.H. (1989) The Netherlands during the Tertiary and Quaternary: a case history of coastal lowlands evolution. Geol. Mijnboum, 68, 107-121.

Zong, Y. \& Tooley, M.J. (1996) Holocene sea-level changes and crustal movements in Morecambe Bay, northwest England. F. Quat. Sci., 11, 43-58.

Manuscript received 17 November 2015; In revised form 1 April 2016; Manuscript accepted 26 April 2016. 